\title{
Conservation of mayflies (Insecta, Ephemeroptera) in Espírito Santo, southeastern Brazil
}

\author{
Fabiana Criste Massariol1,4, Elaine Della Giustina Soares ${ }^{2,3}$ \& Frederico Falcão Salles ${ }^{2}$
}

\begin{abstract}
'Programa de Pós-graduação em Biodiversidade Tropical, Laboratório de Sistemática e Ecologia de Insetos, Universidade Federal do Espírito Santo, Rodovia BR-101 Norte Km 60, Bairro Litorâneo, 29932-540 São Mateus-ES, Brazil.

${ }^{2}$ Departamento de Ciências Agrárias e Biológicas, Centro Universitário Norte do Espírito Santo, Universidade Federal do Espírito Santo, Rodovia BR-101 Norte Km 60, Bairro Litorâneo, 29932-540 São Mateus-ES, Brazil. ffsalles@gmail.com

${ }^{3}$ Present address: Instituto Latino-Americano de Ciências da Vida e da Natureza, Universidade Federal da Integração Latino-Americana, Foz do Iguaçú, Paraná, Brazil. elainedgs@gmail.com

${ }^{4}$ Corresponding author: fcmassariol@gmail.com
\end{abstract}

\begin{abstract}
Conservation of mayflies (Insecta, Ephemeroptera) in Espírito Santo, southeastern Brazil. Ephemeroptera exhibits great diversity among bodies of freshwater in the Atlantic Forest, a biome that is suffering from massive human impact. Within this context, the creation of conservation units using biological information is more recommended than economic, cultural, or political criteria. The distribution pattern of 76 Ephemeroptera species was analyzed using the biogeographical methods Parsimony Analysis of Endemicity and Network Analysis Method in order to infer relevant areas for conservation of the mayfly community in Espírito Santo. The results obtained from both analyses were largely congruent, and pointed out four relevant areas for conservation: two in the south of the state, where conservation units or priority areas for conservation are well established; and two in the north, a region in the state where little conservation efforts have been historically done. Therefore, based on our analyses on mayflies, we recommend the expansion of the existing APCs or the creation of new APCs on the north of Espírito Santo.
\end{abstract}

KEYWORDS. Atlantic Forest; biodiversity; distribution pattern; endemism; macroinvertebrates.

Conservation units are created by public managers and are of great importance to the in situ conservation of species, populations, and ecosystems. In addition to ensuring the preservation of biodiversity, conservation units are an important means of guaranteeing the quality and quantity of the water supply (Medeiros et al. 2011). Approximately $45 \%$ of threatened or endangered species depend on aquatic habitats and wetlands (Clark 1999). Therefore, to delimit and create a conservation unit, it is important to consider the hydrographical basin in which it is located (Clark 1999; Moulton \& Souza 2006). Besides that, despite the above mentioned dependence on aquatic ecosystems, many studies have been conducted based on charismatics species (usually vertebrates), leading to a potentially problematic taxonomic bias in conservation (Clark \& May 2002). In this sense, the use of macroinvertebrates in these kinds of studies is very important.

For the establishment of a conservation unit, economic, cultural, and political factors are more decisive than ecological principles, which are merely one among many criteria for the selection of a preservation site; moreover, there are several biological factors that should be considered (Soulé \& Simberloff 1986). Accordingly, many conservation units have been created in Brazil and also in Espírito Santo without taking into consideration the most appropriate criteria.

The criterion of endemism is utilised to indicate a specific location as a priority for conservation (Carvalho 2004; Chen \& Bi 2007; Löwenberg-Neto 2011). Although there are many concepts used to define areas of endemism, most authors agree that these areas have a significant number of exclusive species (Nelson \& Platnick 1981). Indeed, areas of endemism are biogeographic elements that are used to indicate areas to be conserved because of unique features of biodiversity (Löwenberg-Neto 2011).

The Atlantic Forest is one of the most biodiverse and endangered ecosystems in the world, occupying the fourth position on the hottest hotspots in the world (Myers et al. 2000). It includes a large region that extends over the coastal mountain range along the Atlantic Ocean, in the northeast, southeast, and south regions of Brazil, also including eastern Paraguay and northern Argentina (IPEMA 2005). This biome that originally occupied approximately $90 \%$ of the State of Espírito Santo (southeastern Brazil) was reduced to only 9\% after drastic environmental changes (IPEMA 2005; Passamani 2007). Fragmentation and habitat loss are the largest factors regarded as responsible for the loss of biodiversity and are the main processes contributing to landscape change (Fischer \& Lindenmayer 2007).

Mayflies (Ephemeroptera) exhibit a high diversity and abundance in rivers of various sizes in the Atlantic Forest (Crisci-Bispo et al. 2007; Salles et al. 2010), and play an indispensable role in the food chain participating in the nutrient cycling, providing a food source for fish, birds, and other invertebrates (Waltz \& Burian 2008). This order is the oldest group among winged insects (Britain \& Sartori 2003) and have 
been widely used as bioindicators of water and ecological integrity (Baptista et al. 2007; Buss \& Salles 2007), mainly because they exhibit significant variation in sensitivity to various contaminants including ammonia, nitrite, nitrate, metal, and other chemicals (Hickey \& Clements 1998; Beketov 2004).

The aim of this paper, therefore, is to investigate relevant areas for conservation of the mayfly community in Espírito Santo, Brazil. Besides that, the aim is also to check if the existing conservation units or priority areas for conservation in the state encompass the relevant areas found in this work.

\section{MATERIAL AND METHODS}

Study area. Espírito Santo has an area of $45,597 \mathrm{~km}^{2}$ and is located in southeastern Brazil, bounded by the states of Bahia, Minas Gerais, and Rio de Janeiro in the north, west, and south, respectively (Fig. 1). The topography is mountainous, with elevations ranging from sea level to $2897 \mathrm{~m}$ (IPEMA 2005). The state has 20 ottobasins, at level 04 (Fig. 2): 10 are basins (basins of the São Mateus, São José, Pancas, Santa Maria do Rio Doce, Guandu, José Pedro, Santa Maria da Vitória, Jucu, Itapemirim, and Itabapoana rivers), and 10 are interbasins (interbasins of the Itaúnas, Barra Seca, Norte, Bananal, Córrego do Ouro, Santa Joana, Piraquê-Açu, Aribiri, Benevente, and Córrego São Salvador rivers) (IJSN 2009). The state has 14 federal conservation units and 17 state conservation units, for a total of 31 conservation areas (Fig. 3) occupying $2.66 \%$ of the state area (119,559.8 ha). Most of the conservation units comprise less than 2,500 ha, and only four contain more than 10,000 ha: Reserva Biológica de Sooretama, Parque Nacional do Caparaó, Parque Nacional dos Pontões Capixabas, and Parque Estadual Paulo César Vinha. The first two units together represent the largest continuous forest remnants of the state and have great importance for the conservation of biodiversity (IPEMA 2005).

Projects sponsored by the Ministério do Meio Ambiente (MMA), part of the executive branch of the federal government, have indicated 182 priority areas for conservation (APCs) in Brazil (MMA 2000). Twenty-six APCs are in Espírito Santo (concentrated in the south): 12 of extreme biological importance, 13 of very high importance, and only one of high importance (Fig. 4).

Sampling and identification. We collected nymphs from 48 sampling sites between October 2011 and August 2012
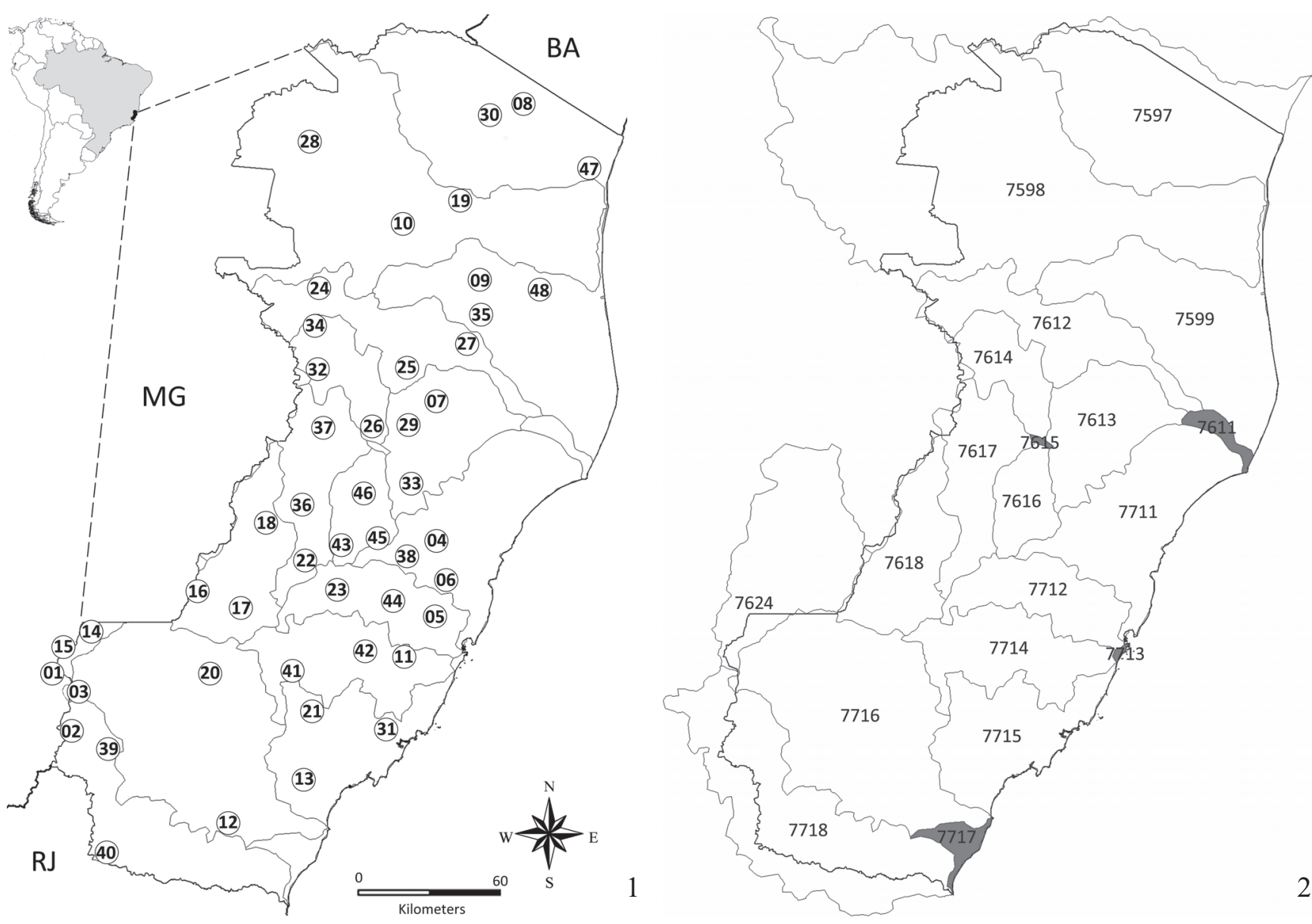

Figs. 1-2. Map of Espírito Santo State. 1. Geographical position of Espírito Santo and the 48 collection points. 2. Hydrographic ottobasins (level 04) in Espírito Santo. Ottobasins in gray were not sampled (Modified from IJSN 2009). 


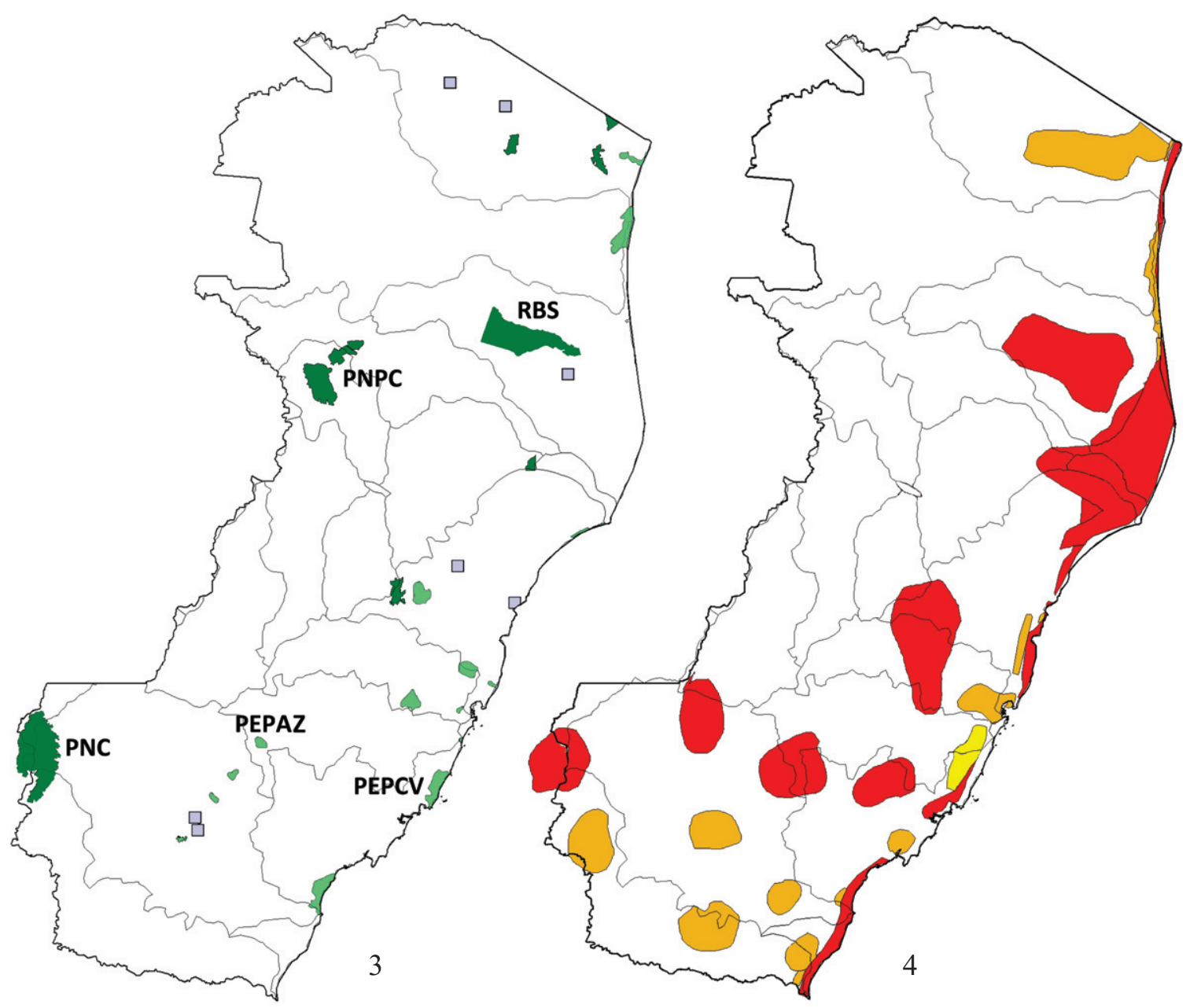

Figs. 3-4. Map of conservation areas in Espírito Santo. 3. Federal, state, and private conservation units (in dark green, light green and light blue respectively). Private reserves are not represented according to their real limits. Acronyms of conservation units mentioned in this paper: RBS, Reserva Biológica de Sooretama. PNPC, Parque Nacional Pontões Capixabas. PNC, Parque Nacional do Capará. PEPAZ, Parque Estadual de Pedra Azul. PEPCV, Parque Estadual Paulo César Vinha (Modified from IPEMA 2005). 4. Priority areas for conservation according to MMA 2000. APCs in red with extremely high priority, in orange with very high priority, and in yellow with high priority.

(Fig. 1, Table I) in Espírito Santo and along its border with Minas Gerais. The sampling points were distributed in a standardised way - three in each ottobasin at different elevations and river widths. This standardisation was employed to obtain a more complete sampling, as these factors directly influence the composition of Ephemeroptera fauna (Domínguez \& Valdez 1992; Baptista et al. 2001; GallardoMayenco 2003). Only four ottobasins were not sampled (interbasins of the Norte, Aribiri, Córrego São Salvador, and Córrego do Ouro rivers) because they are influenced by seawater or have a reduced size (Fig. 2).

In Brazil, hydrographic basins are defined as operating territorial units for management of water resources, according to the law nr. 9433 (BRASIL 1988), and the classification in ottobasins has been used by Conselho Nacional de Recursos Hidricos. Therefore, the choice to work at ottobasins level was because this geographic information system is more appropriate to make decisions on water resources (ANA 2006). Besides, the rapid assessment approaches are enough to show the diversity profile of Ephemeroptera, due to the availability of the immature stages during most of the time (Edmunds et al. 1976) and the easy and inexpensive identification of specimens (Lenat \& Barbour 1994; Resh 1994).

Collections were performed in $50-\mathrm{m}$ stretches in rivers with small to medium widths and in 100-m stretches in large rivers. Ten samples in each section were collected with the aid of D-shaped net (aperture of $0.5 \mathrm{~mm}$ ) in which a sweeping of the shadow area of net was performed. The sampling distribution in each stretch was made according to substrate availability, these included slabs, stone, gravel, sand, root, macrophytes, marginal vegetation, bottom litter, riffle litter. The samples were collected in this way to prevent the sampling effort from influencing the results.

All samples collected were fixed in $80 \%$ ethanol. The identifications were made based on Domínguez et al. (2006) and Salles (2006), assisted when necessary by articles relevant to each taxon. Morphotypes, i.e. Paracloeodes species 1, Paracloeodes species 2, were used for those specimens 
Table I. Sample sites in the state of Espírito Santo and its border with Minas Gerais (Alto Caparaó and Espera Feliz), followed by the municipality, locality, geographic coordinates, and elevations.

\begin{tabular}{|c|c|c|c|c|c|}
\hline Point & Collection date & Municipalities & Locality & Coordenates & Elevation $(\mathrm{m})$ \\
\hline PT 01 & $13 / \mathrm{x} / 2011$ & Alto Caparaó & PARNA Caparaó, Vale Encantado & 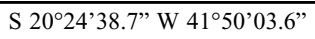 & 1976 \\
\hline PT 02 & $14 / x / 2011$ & Espera Feliz & PARNA Caparaó, Pedra Menina & S $20^{\circ} 37^{\prime} 30.3^{\prime \prime} \mathrm{W} 41^{\circ} 49^{\prime} 27.1^{\prime \prime}$ & 884 \\
\hline PT 03 & $16 / x / 2011$ & Alto Caparaó & PARNA Caparaó, Rio São Domingos, Cachoeira da Farofa & S $20^{\circ} 28^{\prime} 19.5^{\prime \prime} \mathrm{W} 41^{\circ} 49^{\prime} 41.7^{\prime \prime}$ & 1972 \\
\hline PT 04 & $02 / x i / 2011$ & Ibiraçú & Cachoeirão & S $19^{\circ} 53^{\prime} 23.4^{\prime \prime} \mathrm{W} 40^{\circ} 25^{\prime} 42.0^{\prime \prime}$ & 54 \\
\hline PT 05 & 05/xi/2011 & Serra & Distrito de Queimados, Rio Santa Maria & S $20^{\circ} 11^{\prime} 09.7 ” \mathrm{~W} 40^{\circ} 23^{\prime} 08.0^{\prime \prime}$ & 0 \\
\hline PT 06 & $05 / x i / 2011$ & Serra & BR 101, Ponte do Bagaço & S $20^{\circ} 03 ’ 33.7^{\prime \prime} \mathrm{W} 40^{\circ} 22^{\prime} 42.7^{\prime \prime}$ & 9 \\
\hline PT 07 & $08 / x i / 2011$ & Linhares & Cachoeira de Angeli & S $19^{\circ} 20^{\prime} 59.1^{\prime \prime} \mathrm{W} 40^{\circ} 25^{\prime} 17.5^{\prime \prime}$ & 66 \\
\hline PT 08 & $16 / x i / 2011$ & Pedro Canário & Assentamento Castro Alves, Cachoeira da Mata & S $18^{\circ} 12^{\prime} 10.8^{\prime \prime} \mathrm{W} 40^{\circ} 04^{\prime} 37.9^{\prime \prime}$ & 35 \\
\hline PT 09 & $22 / x i / 2011$ & Jaguaré & Santa Maria, Cachoeira do Bereco & S $18^{\circ} 53^{\prime} 04.5^{\prime \prime} \mathrm{W} 40^{\circ} 12^{\prime} 23.1 "$ & 45 \\
\hline PT 10 & $24 / x i / 2011$ & Nova Venécia & Santa Rita do Pip Nuk & S $18^{\circ} 39^{\prime} 51.4^{\prime \prime} \mathrm{W} 40^{\circ} 30^{\prime} 44.9^{\prime \prime}$ & 74 \\
\hline PT 11 & $02 / \mathrm{i} / 2012$ & Viana & Rio Formate & S $20^{\circ} 20^{\prime} 0.90^{\prime \prime} \mathrm{W} 40^{\circ} 30^{\prime} 52.4 "$ & 84 \\
\hline PT 12 & $10 / \mathrm{i} / 2012$ & Atílio Vivacqua & Poço Dantas & S $20^{\circ} 59^{\prime} 12.2^{\prime \prime} \mathrm{W} 41^{\circ} 11^{\prime} 08.1^{\prime \prime}$ & 59 \\
\hline PT 13 & $11 / \mathrm{i} / 2012$ & Rio Novo do Sul & Cachoeira Venezuela & S $20^{\circ} 48^{\prime} 39.33^{\prime \prime} \mathrm{W} 40^{\circ} 53^{\prime} 48.1$ " & 331 \\
\hline PT 14 & $17 / \mathrm{i} / 2012$ & Iúna & Pouso Alto, Rio Pouso Alto & S $20^{\circ} 18^{\prime} 23.1^{\prime \prime} \mathrm{W} 41^{\circ} 44^{\prime} 50.1^{\prime \prime}$ & 329 \\
\hline PT 15 & $17 / \mathrm{i} / 2012$ & Iúna & Bar Hidrolândia, Rio Brás & S $20^{\circ} 19^{\prime} 25.6^{\prime \prime} \mathrm{W} 41^{\circ} 48^{\prime} 45.5^{\prime \prime}$ & 804 \\
\hline PT 16 & $18 / \mathrm{i} / 2012$ & Brejetuba & São Domingos, Fazenda Leogildo & $\mathrm{S} 20^{\circ} 05^{\prime} 13.8^{\prime \prime} \mathrm{W} 41^{\circ} 19^{\prime} 54.1^{\prime \prime}$ & 656 \\
\hline PT 17 & $18 / \mathrm{i} / 2012$ & Afonso Cláudio & Cachoeira Santa Luzia & S $20^{\circ} 09^{\prime} 19.9^{\prime \prime} \mathrm{W} 41^{\circ} 08^{\prime} 32.3^{\prime \prime}$ & 457 \\
\hline PT 18 & $19 / \mathrm{i} / 2012$ & Laranja da Terra & Cachoeira Criminosa & S $19^{\circ} 49^{\prime} 0.30^{\prime \prime} \mathrm{W} 41^{\circ} 00^{\prime} 43.2^{\prime \prime}$ & 232 \\
\hline PT 19 & $27 / \mathrm{i} / 2012$ & São Mateus & Cachoeira Japira & S $18^{\circ} 34^{\prime} 39.1^{\prime \prime} \mathrm{W} 40^{\circ} 16^{\prime} 58.0^{\prime \prime}$ & 8 \\
\hline PT 20 & $30 / 1 / 2012$ & Conceição do Castelo & Rio Castelo, Cachoeira Bicame & S $20^{\circ} 24^{\prime} 07.5^{\prime \prime} \mathrm{W} 41^{\circ} 16^{\prime} 06.5^{\prime \prime}$ & 477 \\
\hline PT 21 & $31 / \mathrm{i} / 2012$ & Alfredo Chaves & Cachoeira Águas de Pinon & S $20^{\circ} 32^{\prime} 58.9^{\prime \prime} \mathrm{W} 40^{\circ} 51^{\prime} 18.8^{\prime \prime}$ & 566 \\
\hline PT 22 & 01/ii/2012 & Itarana & Barra Jatibocas, Rio Jatibocas & S $19^{\circ} 58^{\prime} 45.6^{\prime \prime} \mathrm{W} 40^{\circ} 52^{\prime} 55.5^{\prime \prime}$ & 483 \\
\hline PT 23 & 01/ii/2012 & Santa Maria de Jetibá & Cachoeira Ilha Berger & $\mathrm{S} 20^{\circ} 03^{\prime} 27.5^{\prime \prime} \mathrm{W} 40^{\circ} 46^{\prime} 25.0^{\prime \prime}$ & 709 \\
\hline PT 24 & 07/ii/2012 & Águia Branca & Brejão, Boa Vista, Cachoeira Luizana & $\mathrm{S} 18^{\circ} 55^{\prime} 36.2^{\prime \prime} \mathrm{W} 40^{\circ} 50^{\prime} 25.2^{\prime \prime}$ & 238 \\
\hline PT 25 & 02/iii/2012 & Governador Lindemberg & Fazenda Sugo, Córrego & S $19^{\circ} 14^{\prime} 14.6 " \mathrm{~W} 40^{\circ} 30^{\prime} 09.7 "$ & 147 \\
\hline PT 26 & 29/iii/2012 & Colatina & Cachoeira do Oito & S $19^{\circ} 28^{\prime} 13.8^{\prime \prime} \mathrm{W} 40^{\circ} 36^{\prime} 40.7^{\prime \prime}$ & 70 \\
\hline PT 27 & $12 / \mathrm{iv} / 2012$ & Sooretama & Rio São José & S $19^{\circ} 07^{\prime} 33.1^{\prime \prime} \mathrm{W} 40^{\circ} 14^{\prime} 26.1 "$ & 24 \\
\hline PT 28 & $17 / \mathrm{iv} / 2012$ & Ecoporanga & Cachoeira 2 de setembro & S $18^{\circ} 20^{\prime} 55.9^{\prime \prime} \mathrm{W} 40^{\circ} 52^{\prime} 23.4^{\prime \prime}$ & 366 \\
\hline PT 29 & $23 / \mathrm{iv} / 2012$ & Marilândia & Córrego Limoeiro & S $19^{\circ} 26^{\prime} 10.5^{\prime \prime} \mathrm{W} 40^{\circ} 31^{\prime} 34.7 "$ & 87 \\
\hline PT 30 & $27 / \mathrm{iv} / 2012$ & Montanha & Fazenda Esplanada, Cachoeira Goela da Onça & S $18^{\circ} 14^{\prime} 42.3^{\prime \prime} \mathrm{W} 40^{\circ} 10^{\prime} 43.8^{\prime \prime}$ & 72 \\
\hline PT 31 & $04 / v / 2012$ & Guarapari & Pousada Rio das Pedras & S $20^{\circ} 37^{\prime} 05.9^{\prime \prime} \mathrm{W} 40^{\circ} 34^{\prime} 55.4^{\prime \prime}$ & 35 \\
\hline PT 32 & $14 / v / 2012$ & Pancas & Pratinha, Cachoeira do Bassini & S $19^{\circ} 14^{\prime} 19.6 ” \mathrm{~W} 40^{\circ} 50^{\prime} 49.7 "$ & 189 \\
\hline PT 33 & $15 / v / 2012$ & João Neiva & Acioli, Rio Ubás & S $19^{\circ} 41^{\prime} 09.5^{\prime \prime} \mathrm{W} 40^{\circ} 28^{\prime} 37.2^{\prime \prime}$ & 66 \\
\hline PT 34 & $24 / v / 2012$ & Pancas & Vila Verde, Rio Sumidouro do Pancas, Cachoeira do Gilles & S $19^{\circ} 03 ’ 02.5^{\prime \prime} \mathrm{W} 40^{\circ} 52^{\prime} 27.9^{\prime \prime}$ & 95 \\
\hline PT 35 & $12 / \mathrm{vii} / 2012$ & Sooretama & REBIO Sooretama, Córrego Rodrigues & S $19^{\circ} 01 ’ 36.6^{\prime \prime} \mathrm{W} 40^{\circ} 13^{\prime} 39.0^{\prime \prime}$ & 44 \\
\hline PT 36 & 16/vii/2012 & Itaguaçú & Sobreiro, Cachoeira Cristofari & S $19^{\circ} 45^{\prime} 20.9^{\prime \prime} \mathrm{W} 40^{\circ} 55^{\prime} 45.6^{\prime \prime}$ & 160 \\
\hline PT 37 & $17 /$ vii/2012 & Colatina & Itapina, São Pedro Frio, Córrego na estrada & $\mathrm{S} 19^{\circ} 27^{\prime} 06.6^{\prime \prime} \mathrm{W} 40^{\circ} 48^{\prime} 54.4^{\prime \prime}$ & 265 \\
\hline PT 38 & 30/vii/2012 & Santa Teresa & Córrego na subida de Santa Teresa & S $19^{\circ} 56^{\prime} 13.2^{\prime \prime} \mathrm{W} 40^{\circ} 28^{\prime} 44.1^{\prime \prime}$ & 187 \\
\hline PT 39 & $31 /$ vii/2012 & Guaçuí & São Tiago, Cachoeira do Carlito & S $20^{\circ} 41^{\prime} 56.2^{\prime \prime} \mathrm{W} 41^{\circ} 38^{\prime} 07.4^{\prime \prime}$ & 550 \\
\hline PT 40 & 31/vii/2012 & Bom Jesus do Norte & Ilha do Vicente, Rio Itabapoana & S $21^{\circ} 06^{\prime} 53.6^{\prime \prime} \mathrm{W} 41^{\circ} 41^{\prime} 30.9^{\prime \prime}$ & 64 \\
\hline PT 41 & 01/viii/2012 & Domingos Martins & Cachoeira Floriano & S $20^{\circ} 24^{\prime} 41.5^{\prime \prime} \mathrm{W} 40^{\circ} 56^{\prime} 34.2^{\prime \prime}$ & 1044 \\
\hline PT 42 & 01/viii/2012 & Domingos Martins & Estrada para Cascata do Galo, Rio Jucu Braço Norte & S $20^{\circ} 19^{\prime} 00.2^{\prime \prime} \mathrm{W} 40^{\circ} 39^{\prime} 24.6^{\prime \prime}$ & 464 \\
\hline PT 43 & 02/viii/2012 & Santa Teresa & Cachoeira Zanotti & S $19^{\circ} 55^{\prime} 17.4^{\prime \prime} \mathrm{W} 40^{\circ} 44^{\prime} 38.3^{\prime \prime}$ & 448 \\
\hline PT 44 & 02/viii/2012 & Santa Leopoldina & Rio que passa na estrada para Hospedaria Pau a Pique & S $20^{\circ} 07^{\prime} 36.5^{\prime \prime} \mathrm{W} 40^{\circ} 33^{\prime} 03.6 "$ & 370 \\
\hline PT 45 & 03/viii/2012 & Santa Teresa & Rio 5 de novembro, primeira ponte & $\mathrm{S} 19^{\circ} 52^{\prime} 48.8^{\prime \prime} \mathrm{W} 40^{\circ} 36^{\prime} 38.6^{\prime \prime}$ & 290 \\
\hline PT 46 & 03/viii/2012 & São Roque do Canaã & Rio Santa Maria do Rio Doce, Cachoeira São Pedro & S $19^{\circ} 42^{\prime} 40.3^{\prime \prime} \mathrm{W} 40^{\circ} 39^{\prime} 42.3 ”$ & 69 \\
\hline PT 47 & 04/viii/2012 & Conceição da Barra & Córrego Angelim & S $18^{\circ} 27^{\prime} 09.3 ” \mathrm{~W} 39^{\circ} 47^{\prime} 57.9^{\prime \prime}$ & 1 \\
\hline PT 48 & 04/viii/2012 & Jaguaré & Córrego em Água Limpa & S $18^{\circ} 55^{\prime} 40.4^{\prime \prime} \mathrm{W} 39^{\circ} 59^{\prime} 09.9^{\prime \prime}$ & 40 \\
\hline
\end{tabular}

that did not fit into any species concept. They may represent species new to science or undescribed stages of previously described species. The specimens are deposited in the Coleção Zoológica Norte Capixaba (CZNC) of the Universidade Federal do Espírito Santo (UFES), in São Mateus.

Data analysis. Two methods of historical biogeographic were used to analyse the data: Parsimony Analysis of Ende- micity (PAE) and Network Analysis Method (NAM), both can be used to delimitate areas of endemism. PAE (Morrone 2014) has also been used to indicate priority areas for conservation (e.g., Caviers et al. 2002; Chen \& Bi 2007; Huang et al. 2010) and NAM, recently developed by Dos Santos et $a l$. $(2008,2012)$, to date has not been used for this propose. However, NAM has many advantages when compared to PAE, such as: 1) independence on predefined areas; 2) considers 
earth's curvature; 3 ) evaluates the randomness in data structure; and 4) has a high relative stability of results to scale change (Dos Santos et al. 2008).

Although the collections were conducted quantitatively, the data were analysed qualitatively. After specimen identifications, matrices of presence and absence were constructed for PAE, and a set of species and its respective geographical coordinates were constructed for NAM. The areas resulting from these analyses were not denominated areas of endemism because the species whose geographic distribution extends outside the Espírito Santo area were not excluded from the analyses, so only the distribution within the state was taken into consideration.

Parsimony Analysis of Endemicity. We performed two separate analyses using localities as the operational geographical units: PAE by collection point and PAE by ottobasin. The data matrix was generated in Microsoft ${ }^{\circledR}$ Office Excel 2010, and the taxa were coded as absent (0) or present (1). A hypothetical area coded with zeros was used to root the cladogram; thus, the endemic areas were grouped by the presence of taxa. The matrices were analysed with TNT (Goloboff et al. 2004) using traditional search with 500 replicates. A strict consensus cladogram of the resulting trees was obtained using Winclada 1.0 (Nixon 1999) with fast optimization. The collection points and ottobasins with two or more exclusive species in Espírito Santo were mapped using the programme DIVA-GIS 7.5.0 (Hijmans et al. 2005).

Network Analysis Method. The distribution patterns of species of Ephemeroptera were analysed through NAM based on sympatry inference (Dos Santos et al. 2008, 2012). The analysis was performed using the software R 2.14.2 (R Development Core Team 2011) and the packages SyNet (Dos Santos et al. 2012) and TKRplot (Tierney 2010).

The data were managed to estimate the minimum spanning tree for each species, and the orthodromic distances were calculated. From this result, two matrices of spatial association were inferred: the cost of spatial homogenisation (ACSH) and the topological resemblance (MST). The analysis involved only UCs and diads that satisfied both thresholds, and those that were absent from one of the matrices were discarded. The next step was to choose the cut-off value (maximum distance between the two points considered to be sympatric) used to calculate the basal network. The basal network was achieved from the reweighted topological resemblance $>0.886$ and ACSH $<26.091 \mathrm{~km}$. The binary matrix generated corresponded to the basal network to be analysed by NAM.

UCs are presents in a large network, and existing intermediate species are typically associated with these UCs. Thus, the removal of intermediate species segregates UCs and diads. The resulting cleavogram shows the spatial relationship among the species in a net context and represents a simplified technique to illustrate the division of groups with the removal of intermediate species. The spatial expression patterns of UCs and diads were mapped using the software DIVA-GIS 7.5.0 (Hijmans et al. 2005).

\section{RESULTS}

A total of 76 species (Appendix 1) were found in 48 sampling sites, for a total of 658 distribution records from Espírito Santo and its borders with Minas Gerais and Rio de Janeiro.

PAE by collection point. The analysis of the data matrix (Table II) produced 34 equally parsimonious trees with 432 steps, a consistency index of 17, and a retention index of 19 . The strict consensus cladogram (Fig. 5) showed at the base of the cladogram the presence of six species widely distributed in the state: Americabaetis alphus Lugo-Ortiz \& McCafferty, 1995; Camelobaetidius billi Thomas \& Dominique, 2000; Camelobaetidius rufiventris Boldrini \& Salles, 2009; Paracloeodes eurybranchus Lugo-Ortiz \& McCafferty, 1996; Paracloeodes waimiri Nieto \& Salles, 2006; and Farrodes carioca Dominguez, Molineri \& Peters, 1996. Furthermore, some points or groups showed only one exclusive species: PT 10 (Tricorythopsis rondoniensis Dias, Cruz \& Ferreira, 2009), PT 16 (Lachlania sp. 2), PT 21 (Lachlania sp. 1), PT 35 (Adebrotus lugoi Salles, 2010), PT 37 (Baetodes liviae Polegatto \& Salles, 2008), PT 41 (Paracloeodes sp. 2), PT (26+19(10+27)) (Traverella insolita Nascimento \& Salles, 2013), and PT (10+27) (Harpagobaetis gulosus Mol, 1986).

Four points (Fig. 6) with two or more exclusive species each resulted from the analyses: PT 02 defined by Paracloeodes sp. 1 and Leptohyphodes inanis (Pictet, 1843); PT 08 defined by Callibaetoides caaigua Cruz, Salles \& Hamada, 2013 and Miroculis sp. 1; and PT 42 defined by Spiritiops sp. 1 and Thraulodes sp. 1. Sample site PT 27 showed the highest number of exclusive species, Camelobaetidius juparana Boldrini \& Salles, 2012; Tricorythopsis spongicola Limas, Salles \& Pinheiro, 2011; and Oligoneuria amandae Salles, Soares, Massariol \& Faria, 2014, plus two: Ha. gulosus shared with PT 10 and Ta. insolita shared with PT 16 and 26.

PAE by ottobasin. The analysis of the data matrix (Table III) produced six equally parsimonious trees with 182 steps, a consistency index of 41 , and a retention index of 42 . The strict consensus cladogram (Fig. 7) showed ten ottobasins and groups of them (Figs. 8-9) with two or more exclusive species each. The resulting ottobasins exhibited a nested pattern, with some groups subordinate to others.

All the ottobasins analysed were grouped by eight species: Am. alphus; Americabaetis labiosus Lugo-Ortiz \& McCafferty, 1996; Cm. billi; P. eurybranchus; P. waimiri; Waltzoyphius fasciatus Lugo-Ortiz \& McCafferty, 1995; Tricorythopsis minimus (Allen, 1973); and F. carioca. The basins and interbasins of the Pancas (7614), São Mateus (7598), São José (7612), Guandu (7618), Santa Maria do Rio Doce (7616), Santa Joana (7617), Santa Maria da Vitória (7712), Piraquê-Açu (7711), Bevente (7715), Jucu (7714), Itabapoana (7718), José Pedro (7624), and Itapemirim rivers (7716) were grouped by five exclusive species: Baetodes iuaquita Salles \& Nessimian, 2011; Cm. rufiventris; Leptohyphes plaumanni Allen, 196; Tricorythopsis sp. 1; and Ta. insolita. All the thirteen ottobasins mentioned above 


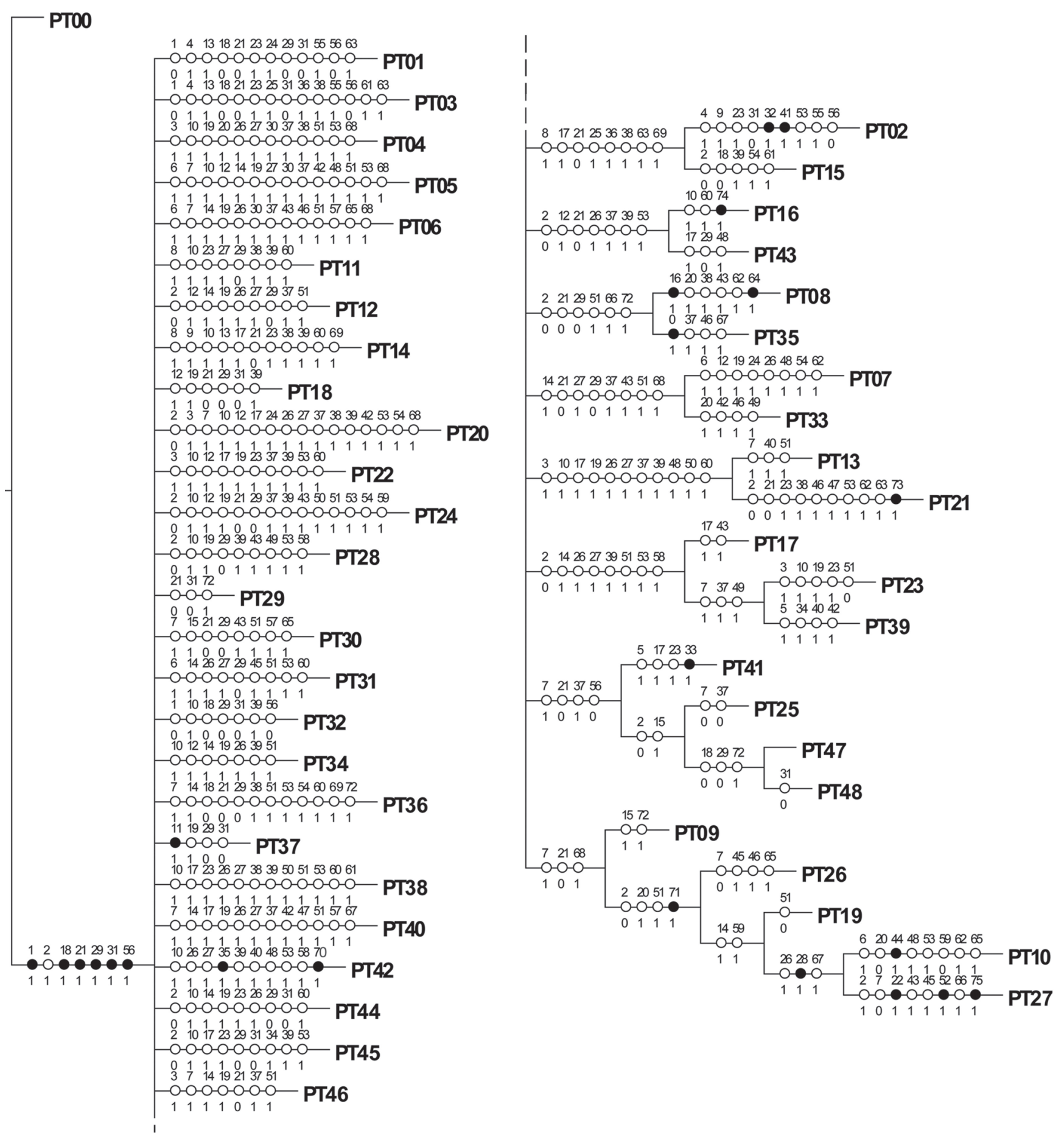

Fig. 5. Strict consensus cladogram (fast optimization) resulting from PAE by collection points. The white circles correspond to homoplasies, and the black circles denote species that occur exclusively in this area. The number above the circles represents species code; number below the circles means present (1) or absent (0).

jointly with the interbasin of the Bananal river (7613) were defined by three exclusive species: Callibaetis sp. 1; Camelobaetidius francischettii Salles, Andrade \& Da-Silva, 2005; and Cloeodes sp. 1.

In the north of the state, the interbasin of the Itaúnas river (7597) showed Cl. caaigua and Miroculis sp. 1 as exclusive species. The basin of the São José river (7612) presented three exclusive taxa: Cm. juparana, Ti. spongicola, and $O$. amandae. These basins in conjunction with the basin of the São Mateus river (7598) were grouped by the presence of the exclusive species Ha. gulosus and Hylister obliquus Nascimento \& Salles, 2013.

The resulting ottobasins in the south of the state had a little more complex hierarchical pattern. The basin of the 


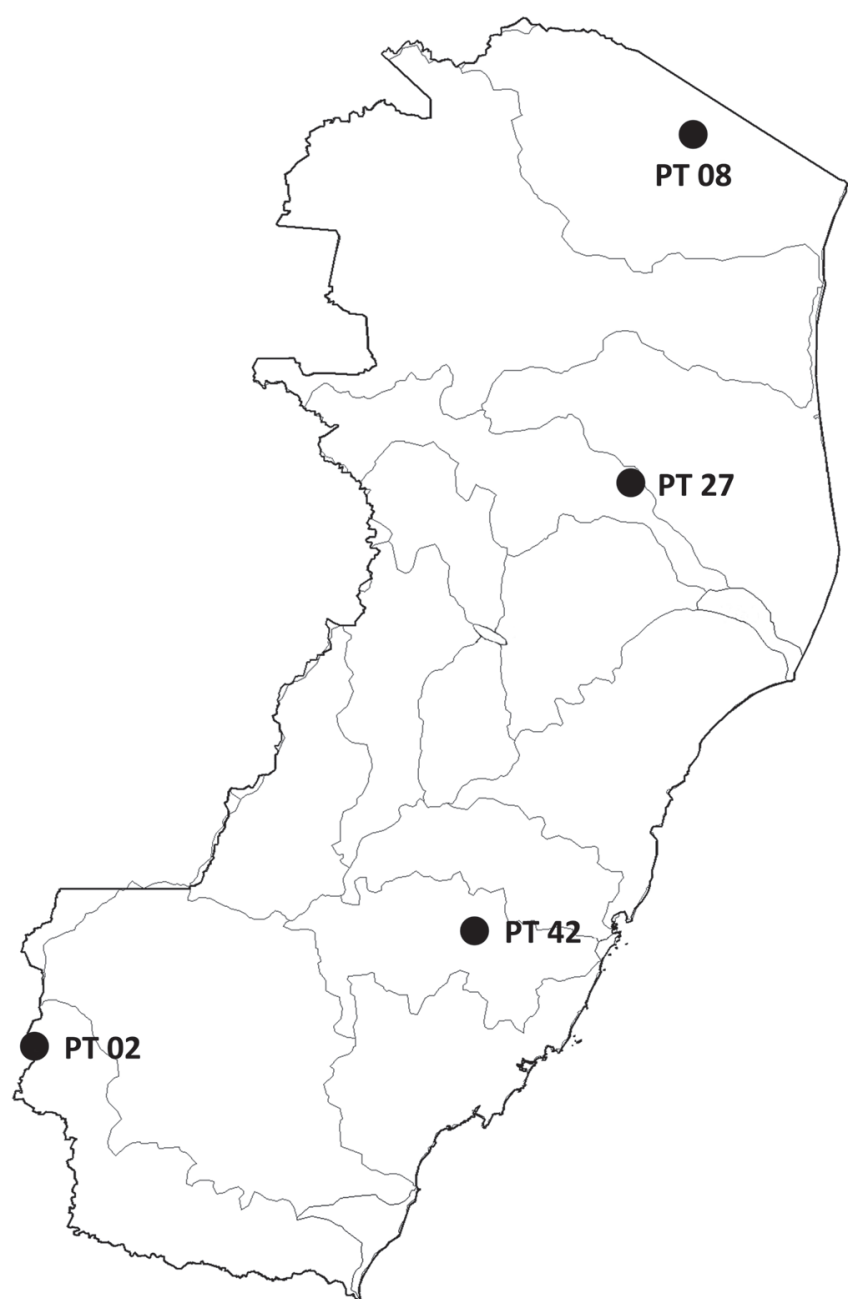

Fig. 6. Spatial expression of collection points resulting from PAE, superimposed on the ottobasin map.

Itabapoana river (7718) presented two exclusive taxa (Paracloeodes sp. 1 and L. inanis), that together with the ottobasins of Itapemirim (7716) and José Pedro (7624) rivers had the unique taxa Americabaetis titthion Lugo-Ortiz \& McCafferty, 1996; Baetodes sp. 2; Cloeodes itajara Massariol \& Salles, 2011; Tupiara ibirapitanga Salles, Lugo-Ortiz, DaSilva \& Francischetti, 2003; and Askola froehlichi Peters, 1969. The basins mentioned above, i.e. $(7716+7624+7718)$, along with the Jucu river basin (7714) shared two exclusive species: Americabaetis sp. 1 and Baetodes sp. 1. Furthermore, in the Jucu river basin (7714) three exclusive taxa were found: Paracloeodes sp. 2, Spiritiops sp. 1, and Thraulodes sp. 1.

Network Analysis Method. After the analyses of 658 records, NAM recognised four UCs and six diads (Table IV, Figs. 10-20) after the removal of 31 intermediary species and eight isolated species.

$\mathrm{UC} 1$ is composed of the distribution area of eight species: As. froehlichi; Am. titthion; Baetodes serratus Needham \& Murphy, 1924; Baetodes sp. 2; Co. itajara; L. inanis; Paracloeodes sp. 1; and Tu. ibirapitanga. The spatial expression of this unit matches the Parque Nacional do Caparaó,

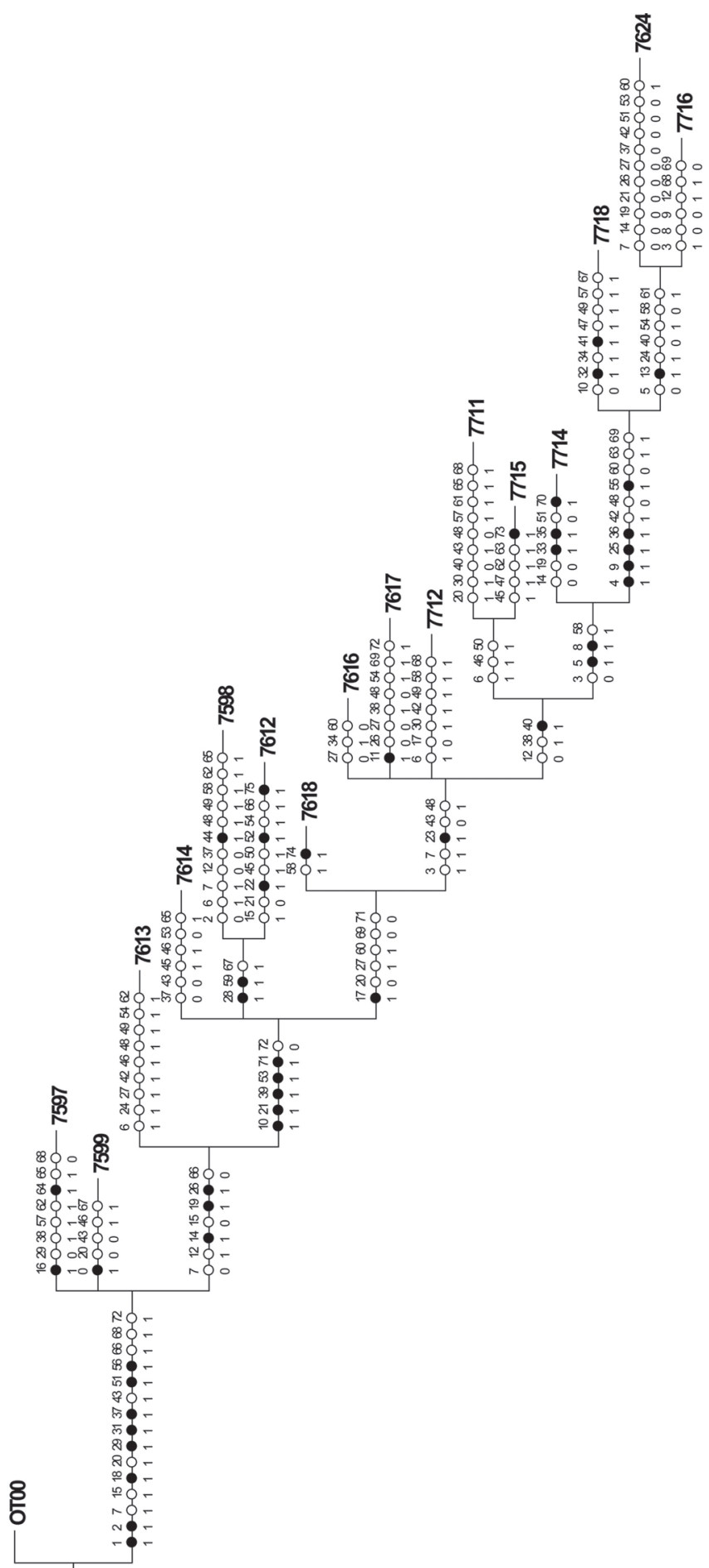

Fig. 7. Strict consensus cladogram (fast optimization) resulting from PAE by ottobasins. The white circles correspond to homoplasies, and the black circles denote species that occur exclusively in this area. The number above the circles represents species code; number below the circles means present (1) or absent (0).

including the collection points PT 01, 02, 03, 14, and 15 (Fig. 17).

UC2 comprises the distribution areas of four species: Americabaetis sp. 1, Spiritiops sp. 1, Thraulodes sp. 1, and Tricorythodes santarita Traver, 1959. This unit is in the cen- 


\begin{tabular}{|c|c|c|c|c|c|c|c|c|}
\hline & & 1 & 2 & 3 & 4 & 5 & 6 & 7 \\
\hline & 0123456789 & 0123456789 & 0123456789 & 0123456789 & 0123456789 & 0123456789 & 0123456789 & 012345 \\
\hline PT 00 & 0000000000 & 0000000000 & 0000000000 & 0000000000 & 0000000000 & 0000000000 & 0000000000 & 000000 \\
\hline PT 01 & 0010100000 & 0001000000 & 0001100000 & 0000000000 & 0000000000 & 0000010000 & 0001000000 & 000000 \\
\hline PT 02 & 0110100011 & 0000000110 & 0001010001 & 0010001010 & 0100000000 & 0001010000 & 0001000001 & 000000 \\
\hline PT 03 & 0010100000 & 0001000000 & 0001010001 & 0000001010 & 0000000000 & 0000010000 & 0101000000 & 000000 \\
\hline PT 04 & 0111000000 & 1000000011 & 1100001101 & 1100000110 & 0000000000 & 0101001000 & 0000000010 & 000000 \\
\hline PT 05 & 0110001100 & 1010100011 & 0100000101 & 1100000100 & 0010000010 & 0101001000 & 0000000010 & 000000 \\
\hline PT 06 & 0110001100 & 0000100011 & 0100001001 & 1100000100 & 0001001000 & 0100001100 & 0000010010 & 000000 \\
\hline PT 07 & 0110001000 & 0010100011 & 0000101100 & 0100000100 & 0001000010 & 0100101000 & 0010000010 & 000000 \\
\hline PT 08 & 0100000000 & 0000001010 & 1000000000 & 0100000010 & 0001000000 & 0100001000 & 0010101000 & 001000 \\
\hline PT 09 & 0110000100 & 0000010010 & 0000000001 & 0100000000 & 0000000000 & 0000001000 & 0000000010 & 001000 \\
\hline PT 10 & 0100001100 & 0000100010 & 0000001011 & 0100000000 & 0000100010 & 0101001000 & 0010010110 & 010000 \\
\hline PT 11 & 0110000010 & 1000000010 & 0101000100 & 0100000011 & 0000000000 & 0000001000 & 1000000000 & 000000 \\
\hline PT 12 & 0100000000 & 0010100011 & 0100001100 & 0100000100 & 0000000000 & 0100001000 & 0000000000 & 000000 \\
\hline PT 13 & 0111000100 & 1000000111 & 0100001101 & 0100000101 & 1000000010 & 1100001000 & 1000000000 & 000000 \\
\hline PT 14 & 0110000011 & 1001000110 & 0001000001 & 0100000011 & 0000000000 & 0000001000 & 1000000001 & 000000 \\
\hline PT 15 & 0100000010 & 0000000100 & 0000010001 & 0100001011 & 0000000000 & 0000101000 & 0101000001 & 000000 \\
\hline PT 16 & 0100000000 & 1010000010 & 0000001001 & 0100000101 & 0000000000 & 0001001000 & 1000000000 & 000010 \\
\hline PT 17 & 0100000000 & 0000100110 & 0100001101 & 0100000001 & 0001000000 & 0101001010 & 0000000000 & 000000 \\
\hline PT 18 & 0110000000 & 0010000011 & 0000000000 & 0000000001 & 0000000000 & 0000001000 & 0000000000 & 000000 \\
\hline PT 19 & 0100000100 & 0000100010 & 1000000001 & 0100000000 & 0000000000 & 0000001001 & 0000000010 & 010000 \\
\hline PT 20 & 0101000100 & 1010000110 & 0100101101 & 0100000111 & 0010000000 & 0001101000 & 0000000010 & 000000 \\
\hline PT 21 & 0101000000 & 1000000111 & 0001001101 & 0100000111 & 0000001110 & 1001001000 & 1011000000 & 000100 \\
\hline PT 22 & 0111000000 & 1010000111 & 0101000001 & 0100000101 & 0000000000 & 0001001000 & 1000000000 & 000000 \\
\hline PT 23 & 0101000100 & 1000100011 & 0101001101 & 0100000101 & 0000000001 & 0001001010 & 0000000000 & 000000 \\
\hline PT 24 & 0100000000 & 1010000011 & 0000000000 & 0100000101 & 0001000000 & 1101101001 & 0000000000 & 000000 \\
\hline PT 25 & 0100000000 & 0000010010 & 0000000001 & 0100000000 & 0000000000 & 0000000000 & 0000000000 & 000000 \\
\hline PT 26 & 0100000000 & 0000000010 & 1000000001 & 0100000000 & 0000011000 & 0100001000 & 0000010010 & 010000 \\
\hline PT 27 & 0110000000 & 0000100010 & 1010001011 & 0100000000 & 0001010000 & 0110001001 & 0000001110 & 010001 \\
\hline PT 28 & 0100000000 & 1000000011 & 0100000000 & 0100000001 & 0001000001 & 0001001010 & 0000000000 & 000000 \\
\hline PT 29 & 0110000000 & 0000000010 & 0000000001 & 0000000000 & 0000000000 & 0000001000 & 0000000000 & 001000 \\
\hline PT 30 & 0110000100 & 0000010010 & 0000000000 & 0100000000 & 0001000000 & 0100001100 & 0000010000 & 000000 \\
\hline PT 31 & 0110001000 & 0000100010 & 0100001100 & 0100000000 & 0000010000 & 0101001000 & 1000000000 & 000000 \\
\hline PT 32 & 0010000000 & 1000000000 & 0100000000 & 0000000001 & 0000000000 & 0000000000 & 0000000000 & 000000 \\
\hline PT 33 & 0110000000 & 0000100010 & 1000000100 & 0100000100 & 0011001001 & 0100001000 & 0000000010 & 000000 \\
\hline PT 34 & 0110000000 & 1010100011 & 0100001001 & 0100000001 & 0000000000 & 0100001000 & 0000000000 & 000000 \\
\hline PT 35 & 1100000000 & 0000000010 & 0000000000 & 0100000100 & 0000001000 & 0100001000 & 0000001100 & 001000 \\
\hline PT 36 & 0110000100 & 0000100000 & 0000000000 & 0100000010 & 0000000000 & 0101101000 & 1000000001 & 001000 \\
\hline PT 37 & 0110000000 & 0100000011 & 0100000000 & 0000000000 & 0000000000 & 0000001000 & 0000000000 & 000000 \\
\hline PT 38 & 0110000000 & 1000000110 & 0101001101 & 0100000011 & 0000000000 & 1101001000 & 1100000000 & 000000 \\
\hline PT 39 & 0100010100 & 0000100010 & 0100001101 & 0100100101 & 1010000001 & 0101001010 & 0000000000 & 000000 \\
\hline PT 40 & 0110000100 & 0000100111 & 0100001101 & 0100000100 & 0010000100 & 0100001100 & 0000000100 & 000000 \\
\hline PT 41 & 0110010100 & 0000000110 & 0001000001 & 0101000100 & 0000000000 & 0000000000 & 0000000000 & 000000 \\
\hline PT 42 & 0110000000 & 1000000010 & 0100001101 & 0100010001 & 1000000010 & 0001001010 & 0000000000 & 100000 \\
\hline PT 43 & 0100000000 & 0010000110 & 0000001000 & 0100000101 & 0000000010 & 0001001000 & 0000000000 & 000000 \\
\hline PT 44 & 0100000000 & 1000100011 & 0101001000 & 0000000000 & 0000000000 & 0000001000 & 1000000000 & 000000 \\
\hline PT 45 & 0100000000 & 1000000110 & 0101000000 & 0000100001 & 0000000000 & 0001001000 & 0000000000 & 000000 \\
\hline PT 46 & 0111000100 & 0000100011 & 0000000001 & 0100000100 & 0000000000 & 0100001000 & 0000000000 & 000000 \\
\hline PT 47 & 0100000100 & 0000010000 & 0000000000 & 0100000100 & 0000000000 & 0000000000 & 0000000000 & 001000 \\
\hline PT 48 & 0100000100 & 0000010000 & 0000000000 & 0000000100 & 0000000000 & 0000000000 & 0000000000 & 001000 \\
\hline
\end{tabular}

tral, north coast, and northwest regions of Espírito Santo and encompasses the collect points PT 26, 27, 31, 42, and 46 (Fig. 18).

$\mathrm{UC} 3$ encompasses the distribution area of seven species: Ad. lugoi, Hy. obliquus, Cm. juparana, O. amandae, Ti. spongicola, Ti. rondoniensis, and Ha. gulosus. This unit is in the north coast and northwest regions and encompasses the collection points PT 10, 19, 24, 27, and 35 (Fig. 19). UCs 2 and 3 overlap at one point, PT 27 (Sooretama, São José river), which has exclusive taxa of the two units.

UC4 is composed of the distribution area of six species: Baetodes santatereza Salles \& Polegatto, 2008; Callibaetis sp. 1; Cm. francischettii; Tricorythopsis gibbus (Allen, 1967); Tricorythopsis araponga Dias \& Salles, 2005; and W. 


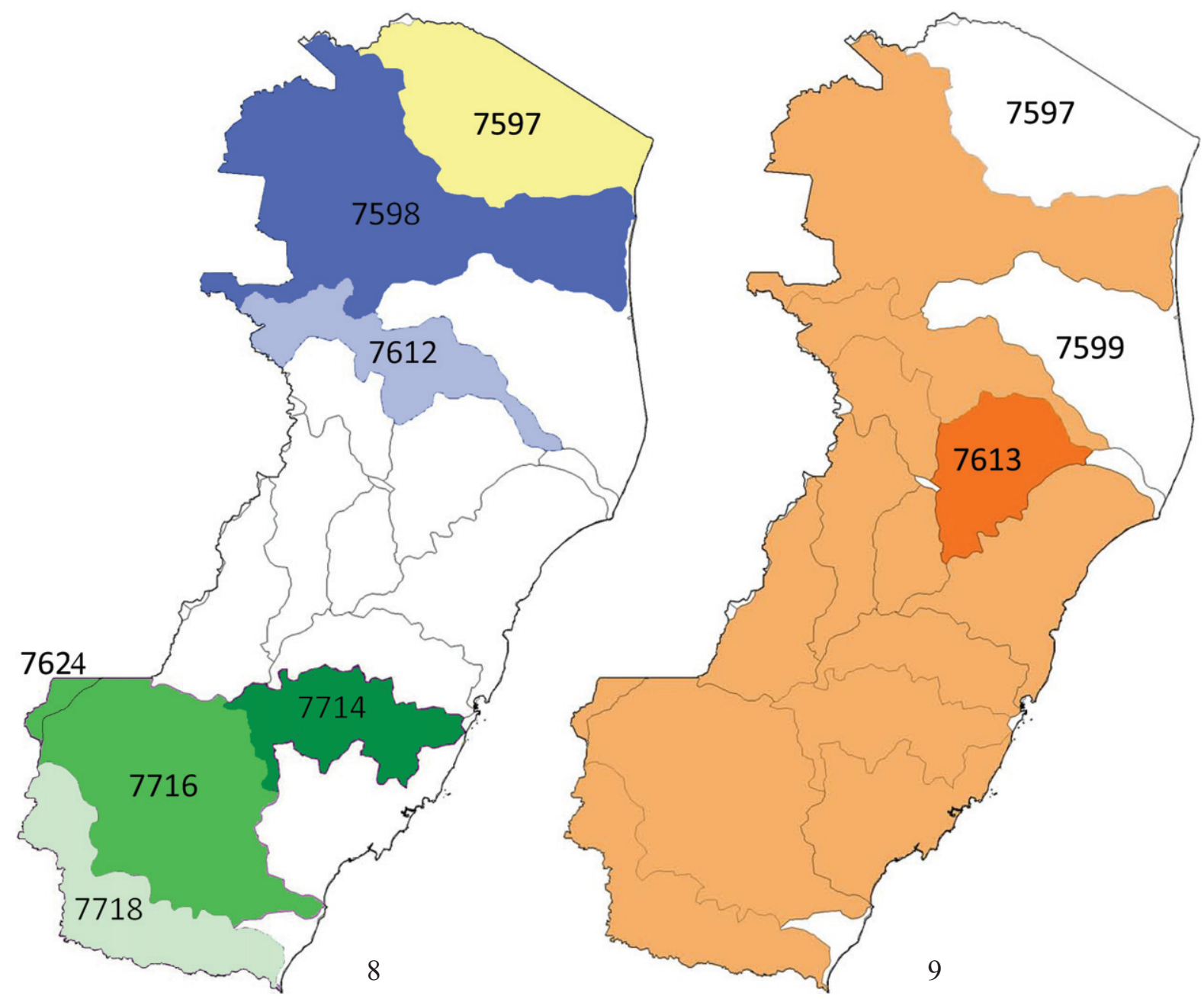

Figs. 8-9. Spatial expression of ottobasins resulting from PAE. 8. Ottobasin in yellow (7597) has two exclusive species. Ottobasin in light blue (7612) has three exclusive taxa, and in conjunction with that in dark blue (7598) have two exclusive species. Ottobasin in light green (7718) has two exclusive taxa, jointly with those in green $(7716,7624)$ have five exclusive taxa. Ottobasin in dark green showed three exclusive species. The four ottobasins in green (light green, green, and dark green) have two exclusive species.

Table III. Matrix with the distribution data of 76 Ephemeroptera species in 16 ottobasins.

\begin{tabular}{|c|c|c|c|c|c|c|c|c|}
\hline & & 1 & 2 & 3 & 4 & 5 & 6 & 7 \\
\hline & 0123456789 & 0123456789 & 0123456789 & 0123456789 & 0123456789 & 0123456789 & 0123456789 & 012345 \\
\hline OT00 & 0000000000 & 0000000000 & 0000000000 & 0000000000 & 0000000000 & 0000000000 & 0000000000 & 000000 \\
\hline 7597 & 0110000100 & 0000011010 & 1000000000 & 0100000110 & 0001000000 & 0100001100 & 0010111000 & 001000 \\
\hline 7598 & 0100001100 & 1000100011 & 1100001011 & 0100000001 & 0001100011 & 0101001011 & 0010010110 & 010000 \\
\hline 7599 & 1110000100 & 0000010010 & 0000000001 & 0100000100 & 0000001000 & 0100001000 & 0000001110 & 001000 \\
\hline 7612 & 0110000000 & 1010110011 & 1010001011 & 0100000101 & 0001010000 & 1111101001 & 0000001110 & 010001 \\
\hline 7613 & 0110001000 & 0010100011 & 1000101101 & 0100000100 & 0011001011 & 0100101000 & 0010000010 & 001000 \\
\hline 7614 & 0110000000 & 1010100011 & 1100001001 & 0100000001 & 0000011000 & 0100001000 & 0000010010 & 010000 \\
\hline 7616 & 0111000100 & 1010100111 & 0101001001 & 0100100101 & 0000000010 & 0101001000 & 0000000000 & 000000 \\
\hline 7617 & 0111000100 & 1110100111 & 0101000001 & 0100000111 & 0000000000 & 0101101000 & 1000000001 & 001000 \\
\hline 7618 & 0110000000 & 1010100111 & 0100001101 & 0100000101 & 0001000000 & 0101001010 & 1000000000 & 000010 \\
\hline 7624 & 0110100011 & 1001000110 & 0001110001 & 0100001011 & 0000000000 & 0000111000 & 1101000001 & 000000 \\
\hline 7711 & 0111001100 & 1000100111 & 1101001101 & 1100000111 & 0001001000 & 1101001100 & 1100010010 & 000000 \\
\hline 7712 & 0111001100 & 1010100011 & 0101001101 & 1100000101 & 0010000011 & 0101001010 & 1000000010 & 000000 \\
\hline 7714 & 0110010110 & 1000000110 & 0101001101 & 0101010111 & 1000000010 & 0001001010 & 1000000000 & 100000 \\
\hline 7715 & 0111001100 & 1000100111 & 0101001101 & 0100000111 & 1000011110 & 1101001000 & 1011000000 & 000100 \\
\hline 7716 & 0111100100 & 1011100111 & 0101111101 & 0100001111 & 0010000000 & 0101111000 & 0101000010 & 000000 \\
\hline 7718 & 0110110111 & 0000100111 & 0101011101 & 0110101111 & 1110000101 & 0101011110 & 0001000101 & 000000 \\
\hline
\end{tabular}




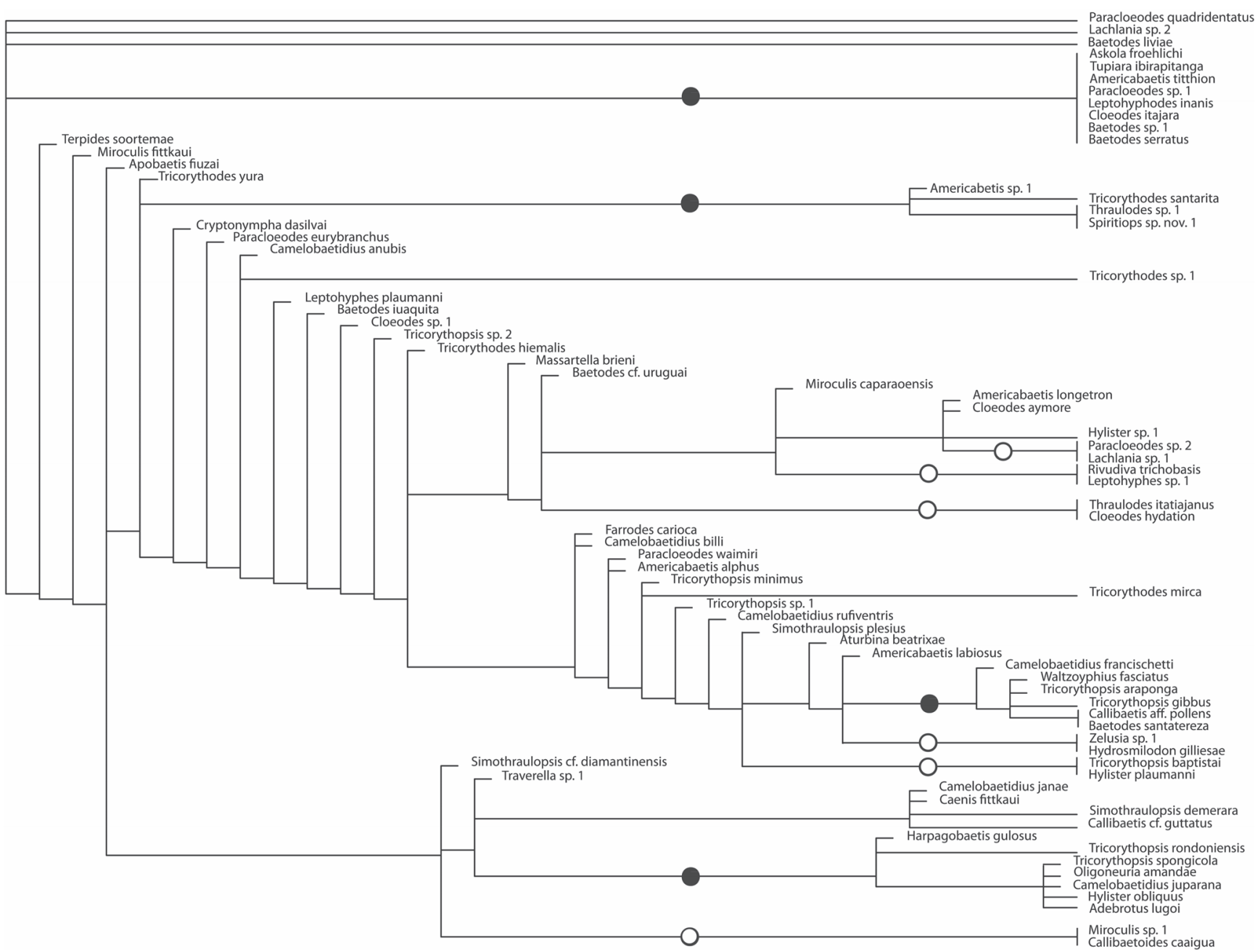

Fig. 10. Cleavogram showing the sequence of the segregation of groups through the removal of intermediary species. The units of co-occurrence are represented by black dots and diads by white dots.

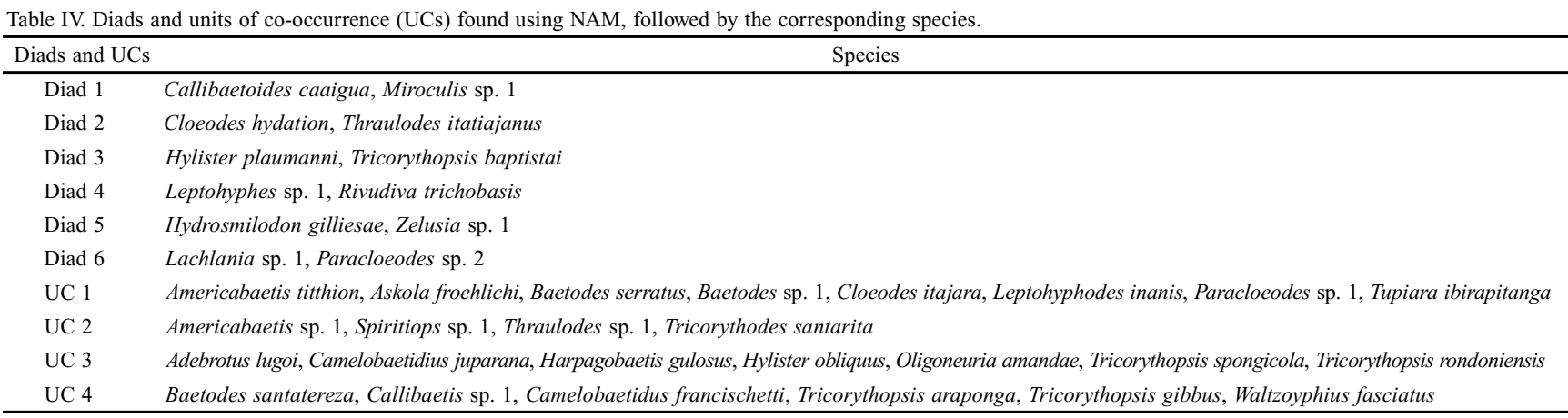

fasciatus. This unit has a very broad spatial expression, with points from north to south (Fig. 20).

Diads 2, 3, and 5 showed a broad spatial expression in the state (Figs. 12, 13, and 15) and are composed of the distribution area of Cloeodes hydation McCafferty \& LugoOrtiz, 1995 - Thraulodes itatiajanus Traver \& Edmunds, 1967; Hylister plaumanni Dominguez \& Flowers, 1989 Tricorythopsis baptistai Dias \& Salles, 2005; and Hydros- milodon gilliesae Thomas \& Péru, 2004 - Zelusia sp. 1, respectively. The remaining diads have a more restricted spatial expression: diad 1 with spatial expression at only one point in the northern state with exclusive taxa $\mathrm{Cl}$. caaigua, and Miroculis sp. 1 (Fig. 11); diad 4 (Fig. 14) and 6 (Fig. 16) both restricted to the south with exclusive taxa Rivudiva trichobasis Lugo-Ortiz \& McCafferty, 1998 - Leptohyphes sp. 1, and Lachlania sp. 1 - Paracloeodes sp. 2, respectively. 

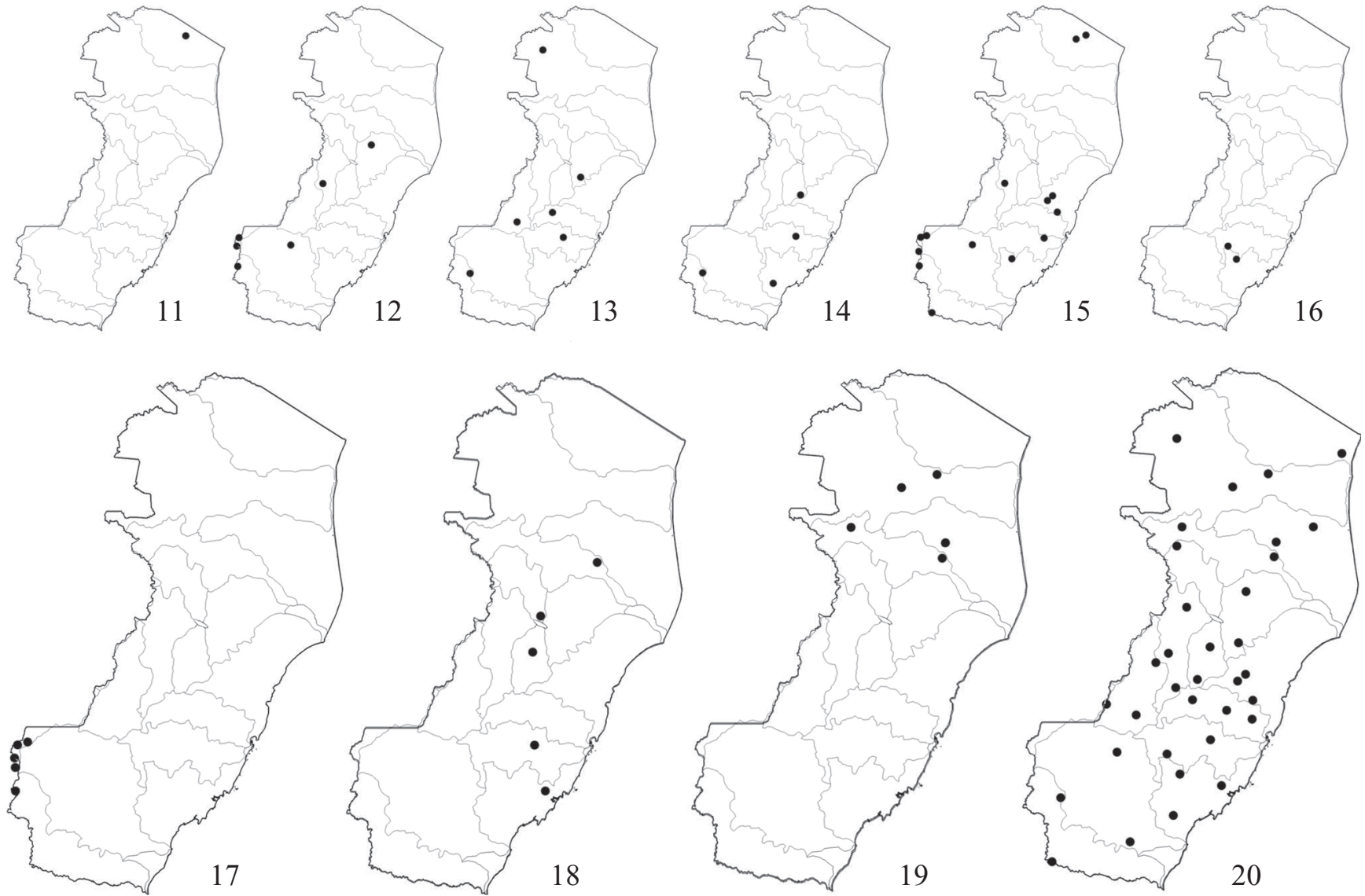

Figs. 11-20. Spatial expression of UCs and diads resulting from NAM. 11. Diad 1. 12. Diad 2. 13. Diad 3. 14. Diad 4. 15. Diad 5. 16. Diad 6. 17. UC 1. 18. UC 2. 19. UC 3. 20. UC 4.

\section{DISCUSSION}

The results of the three analyses were largely congruent, particularly the results of the two approaches using PAE. Considering the total congruence in at least two of the three analyses, the following four relevant areas for conservation of the mayfly community in Espírito Santo were inferred (Fig. 21). Area 1: In the extreme north, this area corresponds to PT 08, ottobasin 7597 (interbasin of the Itaúnas river), and diad 10 and comprises the distribution of two exclusive species: $\mathrm{Cl}$. caaigua and Miroculis sp. 1. Area 2: On the north coast and in the northwest region, this area corresponds to PT 27 and ottobasin 7612 (basin of the São José river) and encompasses the distribution of three exclusive species: $\mathrm{Cm}$. juparana, Ti. spongicola, and O. amandae. Although there was no total congruence between the results of PAE and NAM for this area, PT 27 in the Network Analysis was a point of overlap for two UCs (UC2 and UC3). Area 3: In the central region, this area corresponds to PT 42 and ottobasin 7714 (basin of Jucu river) and is composed of the distribution of three exclusive species: Paracloeodes sp. 2, Spiritiops sp. 1, and Thraulodes sp.1. Area 4: In the south along the border with Minas Gerais, this area corresponds to ottobasins 7718, 7624, and 7716 (the basins of the Itabapoana, José Pedro, and Itapemirim rivers, respectively), containing PT 02 and UC1. This area includes eight exclusive species: As. froehlichi, Am. titthion, B. serratus, Baetodes sp. 2, Co. itajara, L. inanis, Paracloeodes sp. 1, and Tu. ibirapitanga.

The inferred areas for conservation 1 and 4 have the largest number of previously protected areas, with six conservation units each (Fig. 22). Area 1 presents units with a small size (not exceeding 3,000 ha), whereas area 4 contains Parque Nacional do Caparaó, the second largest unit of conservation in Espírito Santo and five other small units. Area 1 is located in the north of the state, a region with few forest fragments due to the severe deforestation occurred in the 19th century by wood exploration and actually by vast eucalyptus plantations (IPEMA 2005; Paula 2006). It is noteworthy that the spatial expression of $\mathrm{UC} 1$ corresponds to the region of Parque Nacional do Caparaó. Area 2 encompasses only a small part of Parque Nacional dos Pontões Capixabas, and area 3 contains only the Parque Estadual de Pedra Azul (Fig. 22); both areas present three exclusive taxa, but the number as well as the size of conservation units area are minimal (not exceeding 1,300 ha). The point PT 27 located in area 2 (corresponding to ottobasin 7612), showed the highest number of exclusive species, besides in NAM analyses PT 27 was a point of contact between UCs 2 and 3, so this area has 


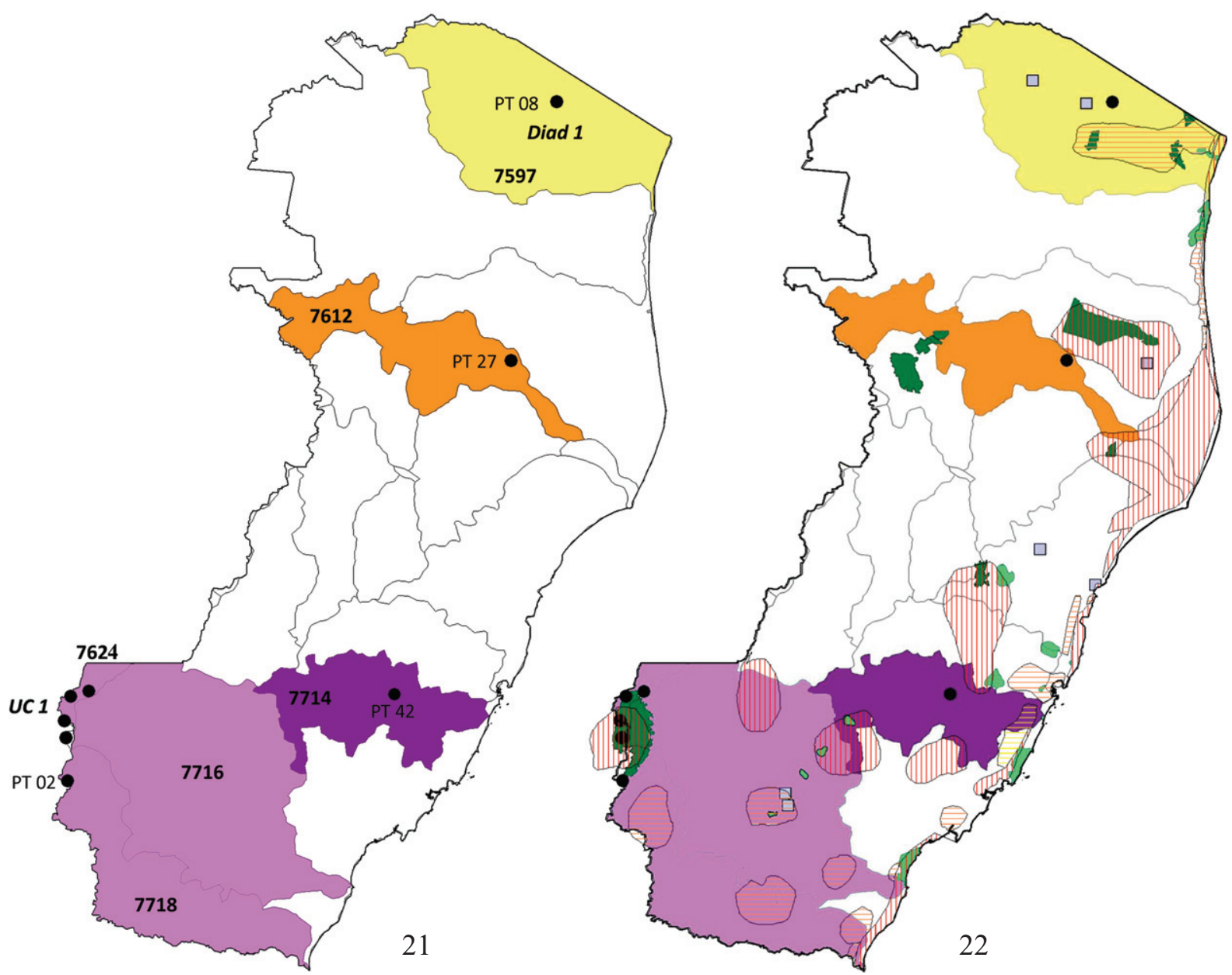

Figs. 21-22. Spatial expression of the congruence of the results of three analyses showing four relevant areas for conservation of the mayfly community. 21. Area 1 - yellow; area 2 - orange, area 3 - purple, area 4 - light purple. PT 02, 08, 27, and 42 resulting from PAE by collection point; 7597, $7612,7714,7716,7718$, and 7624 resulting from PAE by ottobasin, and diad 1 and UC 1 by NAM. 22. Relevant areas for conservation of the mayfly community in Espírito Santo plotted on existing conservation units and priority areas for conservation by MMA. Federal conservation units are in dark green, state in light green, and private reserve in light blue. Red vertical stripes, APCs with extremely high priority; orange horizontal stripes with very high priority; yellow horizontal stripes with high priority.

a high complexity. Despite the ottobasin 7612 being an area that suffer intense anthropogenic pressure (ANA 2001) and be recognized (through PAE and NAM) as one of the relevant areas for conservation, it is unprotected, with only a small part set as a conservation unit in western state. When we compared the inferred areas for conservation (Fig. 21) with APCs of MMA (Fig. 4), we observed that most APCs are in areas 3 and 4 in the southern part of state (Fig. 22). Although area 3 has four APCs all are located marginally. The area 4 is extensive (ottobasins 7624, 7716 and 7718), however the points of exclusive taxa are concentrated in a small area, so the methods showed that this area can be a natural unit. The APCs in area 4 seem to be sufficient and necessary to preserve the biodiversity of the studied group, because they are well distributed spatially, and covers the points of exclusive taxa resulting by PAE and NAM analyses. The contact area between areas 3 and 4 was previously indicated as extremely high priority for conservation. In this work the data suggested that this area is complex, because it is a transition between two areas, so our data corroborate the status given by the MMA assessment.

Unlike the southern portion of the state, northern Espírito Santo is poorly represented by APCs. In this work two areas were pointed out in the north of the state, however only one APC was indicated by MMA, and it is located on area 1 . Despite the area 2 being indicated in this study as a relevant area for conservation of the mayfly community and with a high complexity, the MMA did not pointed out any area within this region as APC. This fact occurs because of two historical and probably dependent reasons: little effort has been done in the north of the state in order to uncover its biodiversity; and, except for Reserva Biológica de Sooretama and Reserva da Vale, only small fragments of forest persist in this area due to agricultural activities. So, this situation makes the region to receive less interest from researches (Moreira et al. 2008).

The north coast of the state is widely suggested as having high priority for conservation according to MMA, however 
the western portion is unprotected by both the lack of conservation units and APCs. Furthermore, the point of contact between UCs 2 and 3 (PT 27) is unprotected by conservation units, and it is not identified as a priority for conservation by MMA. All areas resulting from the analyses present at least one conservation unit or one portion of APC with the exception of point PT 27 in the north of Espírito Santo. Therefore, it is recommended that the existing APCs be expanded to integrate the relevant areas for conservation of the mayfly community inferred in this work, or the creation of new APCs particularly on the north of Espírito Santo.

\section{ACKNOWLEDGMENTS}

We are grateful to Conselho Nacional de Desenvolvimento Científico e Tecnológico (CNPq, grants 402939/2012-3, 245924/2012-4) and Fundação de Apoio à Ciência e Tecnologia do Espírito Santo (FAPES, grants 54689627/ 2011, 511187434/2010) for financial support; IBAMA (Instituto Brasileiro do Meio Ambiente e dos Recursos Naturais Renováveis) for collecting permits; Ezinete Moreira do Rozário for her invaluable support with the fieldwork; to Coordenação de Aperfeiçoamento de Pessoal de Nível Superior (CAPES) for scholarship provided to the first author and to CNPq for research scholarship provided to the third author (grant 306670/2012-7). To Carlos Molineri for his help with biogeographic methods, and to Luisa Maria Soares Porto and Mateus Pepinelli for their contributions to dissertations that originated this work.

\section{REFERENCES}

ANA - Agência Nacional de Águas. 2001. Bacias Hidrográficas do Attântico Sul - trecho leste. Sinopse de informações do Rio de Janeiro, Espírito Santo, Bahia e Sergipe. Série: Sistema Nacional de Informações sobre Recursos Hídricos - CD n. 4. Available at: http://hidroweb.ana.gov.br/ doc/BHASLeste/index.htm (accessed 10 February 2014).

ANA - Agência Nacional de Águas. 2006. Topologia Hídrica: Método de Construção e Modelagem da Base Hidrográfica para Suporte à Gestão de Recursos Hídricos - Versão 1.11. Brasília, ANA - Agência Nacional de Águas, SGI - Superintendência de Gestão da Informação, 29 p.

Baptista, D.F., Buss, D.F., Dorvillé, L.F.M. \& Nessimian, J.L. 2001. Diversity and habitat preference of aquatic insects along the longitudinal gradient of the Macaé River Basin, Rio de Janeiro, Brazil. Revista Brasileira de Biologia 61: 249-258.

Baptista, D.F., Buss, D.F., Egler, M., Giovanelli, A., Silveira, M.P. \& Nessimian, J.L. 2007. A multimetric index based on benthic macroinvertebrates for evaluation of Atlantic Forest streams at Rio de Janeiro State, Brazil. Hydrobiologia 575: 83-94.

Beketov, M.A. 2004. Different sensitivity of mayflies (Insecta, Ephemeroptera) to ammonia, nitrite and nitrate: linkage between experimental and observational data. Hydrobiologia 528: 209-216.

BRASIL. 1988. Constituição da República Federativa do Brasil. Texto constitucional promulgado em 5 de outubro de 1988 , com as alterações adotadas pelas Emendas Constitucionais nos 1/1992 a 68/2011, pelo Decreto Legislativo no186/2008 e pelas Emendas Constitucionais de Revisão nos 1 a 6/1994, Brasília.

Britain, J.E. \& Sartori, M. 2003. Ephemeroptera (Mayflies), p. 373-380. In: Resh, V.H. \& Cardé, R.T. (Eds.). Encyclopedia of Insects. California, Academic Press, an imprint of Elsevier Science, 1295 p.
Buss, D.F. \& Salles, F.F. 2007. Using Baetidae species as biological indicators of environmental degradation in a Brazilian river basin. Environmental Monitoring and Assessment 130: 365-372.

Carvalho, C.J.B. 2004. Ferramentas atuais da Biogeografia histórica para utilização em conservação, p. 92-103. In: Milano, M.S., Takahashi, L.Y. \& Nunes, M.L. (Eds.). Unidades de Conservação: atualidades e tendências. Curitiba, Fundação o Boticário de Proteção da Natureza, $224 \mathrm{p}$.

Cavieres, L.A., Arroyo, M.T.K., Posadas, P., Marticorena, C., Matthei, O., Rodríguez, R., Squeo, F.A. \& Arancio, G. 2002. Identification on priority areas for conservation in an arid zone: application of parsimony analysis of endemicity in the vascular flora of the Antofagasta region, northern Chile. Biodiversity and Conservation 11: $1301-1311$.

Chen, Y. \& Bi, J. 2007. Biogeography and hotspots of amphibian species of China: Implications to reserve selection and conservation. Research Articles 92: 480-489.

Clark, J.R. 1999. The ecosystem approach from a practical point of view. Conservation Biology 13: 679-681.

Clark, J.A. \& May, R.M. 2002. Taxonomic bias in conservation research. Science 297: 191-192.

Crisci-Bispo, V.L., Bispo, P.C. \& Froehlich, C.G. 2007. Ephemeroptera, Plecoptera and Trichoptera assemblages in litter in a mountain stream of the Atlantic Rainforest from Southeastern Brazil. Revista Brasileira de Zoologia 24: 545-551.

Domínguez, E. \& Valdez, J.M.B. 1992. Altitudinal replacement of Ephemeroptera in a subtropical river. Hydrobiologia 246: 83-88.

Domínguez, E., Molineri, C., Pescador, MI., Hubbard, M.D. \& Nieto, C. 2006. Ephemeroptera of South America. In: Adis, J.R., Rueda-Delgado, G \& Wantzen, K.W. (eds.) Aquatic Biodiversity of Latin America. Vol. 2, Sofia, Pensoft Publishers, 646 p.

Dos Santos, D.A., Fernández, H.R., Cuezzo, M.G. \& Domínguez, E. 2008. Sympatry inference and network analysis in Biogeography. Systematic Biology 57: 432-448.

Dos Santos, D.A., Cuezzo, M.G., Reynaga, M.C. \& Domínguez, E. 2012. Towards a dynamic analysis of weighted networks in Biogeography. Systematic Biology 61: 240-252.

Edmunds, G.F., Jr., Jensen, S.L. \& Boner, L. 1976. The biological role of mayflies, p. 3-50. In: Edmunds, G.F., Jr., Jensen, S.L. \& Boner, L. (Eds.). The mayflies of North and Central America. Minneapolis, University of Minnesota Press, $x+330 p$.

Fischer, J. \& Lindenmayer, D.B. 2007. Landscape modification and habitat fragmentation: a synthesis. Global Ecology and Biogeography 16: $265-280$.

Gallardo-Mayenco, A. 2003. Distribuición espacial de los efemerópteros (Insecta: Ephemeroptera) en dos cuencas mediterráneas a diferentes altitudes. Zoological Baetica 13/14: 93-110.

Goloboff, P., Farris, S. \& Nixon, K. 2004. T.N.T. - Tree analysis using new technology. Available at: http://www.cladistics.com (accessed 05 December 2012).

Hickey, C.W. \& Clements, W.H. 1998. Effects of heavy metals on benthic macroinvertebrate communities in New Zealand streams. Environmental Toxicology and Chemistry 17: 2338-2346.

Hijmans, R.J., Guarino, L., Bussink, C., Mathur, P., Cruz, M., Barrentes, I. \& Rojas, E. 2005. DIVA-GIS: A geographic information system for the analysis of species distribution data, version 5.2. Available at: http://www.diva-gis.org (accessed 05 December 2012).

Huang, X.-L., Qiao, G.-X. \& Lei, F.-M. 2010. Use of parsimony analysis to identify areas of endemism of Chinese birds: Implications for conservation and biogeography. International Journal of Molecular Sciences 11: 2097-2108.

IJSN - Instituto Jones dos Santos Neves. 2009. Ottobacias Hidrográficas do Espírito Santo - Nível 04. Espírito Santo. Escala 1: 2.000.000.

IPEMA - Instituto de Pesquisas da Mata Atlântica. 2005. Conservação da Mata Atlântica no Estado do Espírito Santo: Cobertura florestal e Unidades de Conservação. Secretaria de Meio Ambiente e Recursos Hídricos, Espírito Santo, 152 p. 
Lenat, D.R. \& Barbour, M.T. 1994. Using benthic macroinvertebrate community structure for rapid, cost-effective, water quality monitoring: Rapid bioassessment, p. 187-215. In: Loeb, S.L. \& Spacie, A. (Eds.). Biological Monitoring of Aquatic Systems. 1st ed. Washington DC, Lewis Publishers, $400 \mathrm{p}$.

Löwenberg-Neto, P. 2011. Conservação da biodiversidade e biogeografia histórica, p. 162-172. In: Carvalho, C.J.B. \& Almeida, E.A.B. (Eds.). Biogeografia da América do Sul - Padrões e Processos. São Paulo, Editora Roca, 306 p.

Medeiros, R., Young, C.E.F., Pavese, H.B. \& Araújo, F.F.S. 2011. Unidades de conservação e sua importância para a conservação da biodiversidade, p. 8-12. In: Medeiros, R., Young, C.E.F., Pavese, H.B \& Araújo, F.F.S. (Eds.). Contribuição das Unidades de Conservação para a Economia Nacional: Sumário Executivo. Brasília, UNEP-WCMC, 44 p.

MMA - Ministério do Meio Ambiente. 2000. Avaliação e ações prioritárias para a conservação da biodiversidade da Mata Atlântica e Campos Sulinos. Conservation International do Brasil/Fundação SOS Mata Atlântica/Fundação Biodiversitas/Instituto de Pesquisas Ecológicas/ Secretaria do Meio Ambiente do Estado de São Paulo SEMAD/Instituto Estadual de Florestas-MG, Brasília, 45 p.

Moreira, D.O., Coutinho, B.R. \& Mendes, S.L. 2008. O status do conhecimento sobre a fauna de mamíferos do Espírito Santo baseado em registros de museus e literatura científica. Biota Neotropica 8: 163173.

Morrone, J.J. 2014. Parsimony analysis of endemicity (PAE) revisited. Journal of Biogeography 41: 842-854.

Moulton, T.P. \& Souza, M.L. 2006. Conservação com base em bacias hidrográficas, p. 157-182. In: Rocha, C.F.D., Bergallo, H.G., Sluys, M.V. \& Alves, M.A.S. (Eds.). Biologia da Conservação: Essências. São Carlos, RiMa Editora, 582 p.

Myers, N., Mittermeier, R.A., Mittermeier, C.G., Fonseca, G.A.B. \& Kent, J. 2000. Biodiversity hotspots for conservation priorities. Nature 403: $853-858$.
Nelson, G. \& Platnick, N.I. 1981. Systematics and biogeography: cladistics and vicariance. Columbia Press University, xi+567 p.

Nixon, K.C. 1999. Winclada versão 1.0. Available at: http://www.cladistics.com/ about_winc.htm (accessed 05 December 2012).

Passamani, M. 2007. Situação atual da fauna ameaçada de extinção no Estado do Espírito Santo, p. 15-20. In: Passamani, M. \& Mendes, S.L. (Orgs.). Espécies da Fauna Ameaçadas de Extinção no Estado do Espírito Santo. Vitória, IPEMA - Instituto de Pesquisas da Mata Atlântica, 140 p.

Paula, A. 2006. Espírito Santo, p. 114-128. In: Campanili, M. \& Prochnow, M. (Eds.). Mata Atlântica - Uma rede pela floresta. Brasília, Rede ONGs pela Mata Atlântica, RMA, 334 p.

R Development Core Team. 2011. R: A language and environment for statistical computing. R Foundation for Statistical Computing, Vienna, Austria. Available at: http://www.R-project.org/(accessed 05 December 2012).

Resh, V.H. 1994. Variability, accuracy, and taxonomic costs of rapid assessment approaches in benthic macroinvertebrate biomonitoring. Bolettino di Zoologia 61: 375-383.

Salles, F.F. 2006. A ordem Ephemeroptera no Brasil (Insecta): Taxonomia e diversidade. Ph. D. Dissertation, Universidade Federal de Viçosa, 313 p.

Salles, F.F., Nascimento, J.M.C., Massariol, F.C., Angeli, K.B., Silva, P.B., Rúdio, J.A. \& Boldrini, R. 2010. Primeiro levantamento da fauna de Ephemeroptera (Insecta) do Espírito Santo, Sudeste do Brasil. Biota Neotropica 10: 293-307.

Soulé, M.E. \& Simberloff, D. 1986. What do genetics and ecology tell us about the design of nature reserver? Biological Conservation 35: 19-40.

Tierney, L. 2010. tkrplot: Tk R Plot. R package version 0.0-19. Available at: http://CRAN.R-project.org/package $=$ tkrplot $($ accessed 05 December 2012).

Waltz, R.D. \& Burian, S.K. 2008. Ephemeroptera, p. 181-236. In: Merrit, R.W., Cummins, K.W. \& Berg, M.B. (Eds.). An introduction to the aquatic insects of North America. 4th ed. Kendall/Hunt Publishing Company, 1214 p.

Appendix 1. Species list with respective codes used for PAE and the collection points that taxa occurs. Species that occur exclusively in Espírito Santo are followed by an Appendix

\begin{tabular}{|c|c|c|}
\hline Species code & Taxa & Collection points (PT) \\
\hline 0 & Adebrotus lugoi* Salles, 2010 & 35 \\
\hline 1 & Americabaetis alphus Lugo-Ortiz \& McCafferty, 1996 & $02,04-31,33-48$ \\
\hline 2 & Americabaetis labiosus Lugo-Ortiz \& McCafferty, 1996 & $01-07,09,11,13,14,18,22,27,29,30-34,36-38,40-42,46$ \\
\hline 3 & Americabaetis longetron Lugo-Ortiz \& McCafferty, 1996 & $04,13,20-23,46$ \\
\hline 4 & Americabaetis titthion Lugo-Ortiz \& McCafferty, 1996 & $01-03$ \\
\hline 5 & Americabaetis sp. 1 & 39,41 \\
\hline 6 & Apobaetis fiuzai Salles \& Lugo-Ortiz, 2002 & $05-07,10,31$ \\
\hline 7 & Aturbina beatrixae Gillies, 2001 & $05,06,09,10,13,19,20,23,30,36,39-41,46-48$ \\
\hline 8 & Baetodes sp. 1 & $02,11,14,15$ \\
\hline 9 & Baetodes sp. 2 & 02,14 \\
\hline 10 & Baetodes iuaquita* Salles \& Nessimian, 2011 & $04,05,11,13,14,16,20-24,28,32,34,38,42,44,45$ \\
\hline 11 & Baetodes liviae Polegatto \& Salles, 2008 & 37 \\
\hline 12 & Baetodes santatereza* Salles \& Polegatto, 2008 & $05,07,12,16,18,20,22,24,34,43$ \\
\hline 13 & Baetodes serratus Needham \& Murphy, 1924 & $01,03,14$ \\
\hline 14 & Callibaetis sp. 1 & $05-07,10,12,17,19,23,27,31,33,34,36,39,40,44,46$ \\
\hline 15 & Callibaetis sp. 2 & $09,25,30,47,48$ \\
\hline 16 & Callibaetoides caaigua Cruz, Salles \& Hamada, 2013 & 08 \\
\hline 17 & Camelobaetidius anubis (Traver \& Edmunds, 1968) & $02,13-15,17,20-22,38,40,41,43,45$ \\
\hline 18 & Camelobaetidius billi Thomas \& Dominique, 2000 & $02,04-14,16-31,33-35,37-46$ \\
\hline 19 & Camelobaetidius francischetti Salles, Andrade \& Da-Silva, 2005 & $04-07,12,13,18,21-24,28,34,37,40,44,46$ \\
\hline 20 & Camelobaetidius janae Dominique \& Thomas, 2000 & $04,08,19,26,27,33$ \\
\hline 21 & Camelobaetidius rufiventris Boldrini \& Salles, 2009 & $04-06,11-13,17,20,22,23,28,31,32,34,37-40,42,44,45$ \\
\hline 22 & Camelobaetidius juparana Boldrini \& Salles, 2012 & 27 \\
\hline 23 & Cloeodes aymore* Massariol \& Salles, 2011 & $01-03,11,14,21-23,38,41,44,45$ \\
\hline 24 & Cloeodes hydation McCafferty \& Lugo-Ortiz, 1995 & $01,07,20$ \\
\hline
\end{tabular}


Appendix 1. Continued.

\begin{tabular}{|c|c|c|}
\hline Species code & Taxa & Collection points $(\mathrm{PT})$ \\
\hline 25 & Cloeodes itajara* Massariol \& Salles, 2011 & $02,03,15$ \\
\hline 26 & Cloeodes sp.1 & $04,06,07,10,12,13,16,17,20,21,23,27,31,34,38-40,42-44$ \\
\hline 27 & Cryptonympha dasilvai Lugo-Ortiz \& McCafferty, 1998 & $04,05,07,11-13,17,20,21,23,31,33,38-40,42$ \\
\hline 28 & Harpagobaetis gulosus Mol, 1986 & 10,27 \\
\hline 29 & Paracloeodes eurybranchus Lugo-Ortiz \& McCafferty, 1996 & $02-06,09,10,13-17,19-23,25-27,29,34,38-42,46$ \\
\hline 30 & Paracloeodes quadridentatus Lima \& Salles, 2010 & $04-06$ \\
\hline 31 & Paracloeodes wamiri Nieto \& Salles, 2006 & $04-17,19-28,30,31,33-36,38-43,46,47$ \\
\hline 32 & Paracloeodes sp. 1 & 02 \\
\hline 33 & Paracloeodes sp. 2 & 41 \\
\hline 34 & Rivudiva trichobasis Lugo-Ortiz \& McCafferty, 1998 & 39,45 \\
\hline 35 & Spiritiops sp. 1 & 42 \\
\hline 36 & Tupiara ibirapitanga Salles, Lugo-Ortiz, Da-Silva \& Francischetti, 2003 & $02,03,15$ \\
\hline 37 & Waltzoyphius fasciatus Lugo-Ortiz \& McCafferty, 1995 & $04-07,12,13,16,20-24,33,35,39-41,43,46-48$ \\
\hline 38 & Zelusia sp. 1 & $02-04,08,11,14,15,20,21,36,38$ \\
\hline 39 & Leptohyphes plaumanni Allen, 1967 & $11,13-18,20-24,28,32,34,38,39,42,43,45$ \\
\hline 40 & Leptohyphes sp. 1 & $13,39,42$ \\
\hline 41 & Leptohyphodes inanis (Pictet, 1843) & 02 \\
\hline 42 & Tricorythodes hiemalis Molineri, 2001 & $05,20,33,39,40$ \\
\hline 43 & Tricorythodes mirca Molineri, 2002 & $06-08,17,24,27,28,30,33$ \\
\hline 44 & Tricorythopsis rondoniensis Dias, Cruz \& Ferreira, 2009 & 10 \\
\hline 45 & Tricorythodes santarita Traver, 1959 & $26,27,31$ \\
\hline 46 & Tricorythodes yura Molineri, 2002 & $06,21,26,33,35$ \\
\hline 47 & Tricorythodes sp. 1 & 21,40 \\
\hline 48 & Tricorythopsis araponga Dias \& Salles, 2005 & $05,07,10,13,21,42,43$ \\
\hline 49 & Tricorythopsis baptistai Dias \& Salles, 2005 & $23,28,33,39$ \\
\hline 50 & Tricorythopsis gibbus (Allen, 1967) & $13,21,24,38$ \\
\hline 51 & Tricorythopsis minimus (Allen, 1973) & $04-08,10,12,13,17,24,26,27,30,31,33-36,38-40,46$ \\
\hline 52 & Tricorythopsis spongicola Limas, Salles \& Pinheiro, 2011 & 27 \\
\hline 53 & Tricorythopsis sp. 1 & $02,04,05,10,16,17,20-24,28,31,36,38,39,42,43,45$ \\
\hline 54 & Tricorythopsis sp. 2 & $07,15,20,24,36$ \\
\hline 55 & Askola froehlichi Peters, 1969 & $01-03$ \\
\hline 56 & Farrodes carioca Dominguez, Molineri \& Peters, 1996 & $04-24,26-31,33-40,42-46$ \\
\hline 57 & Hydrosmilodon gilliesae Thomas \& Péru, 2004 & $06,30,40$ \\
\hline 58 & Hylister plaumanni Dominguez \& Flowers, 1989 & $17,23,28,39,42$ \\
\hline 59 & Hylister obliquus* Nascimento \& Salles, 2013 & $19,24,27$ \\
\hline 60 & Hylister sp. 1 & $11,13,14,16,21,22,31,36,38,44$ \\
\hline 61 & Massartella brieni (Lestage, 1924) & $03,15,38$ \\
\hline 62 & Miroculis fittkaui Savage \& Peters, 1983 & $07,08,10,21$ \\
\hline 63 & Miroculis caparaoensis* Salles \& Lima, 2011 & $01-03,15,21$ \\
\hline 64 & Miroculis sp. 1 & 08 \\
\hline 65 & Simothraulopsis (Simothraulopsis) demerara (Traver, 1947) & $06,10,26,30$ \\
\hline 66 & Simothraulopsis sp. 1 & $08,27,35$ \\
\hline 67 & Simothraulopsis (Maculognathus) plesius Kluge, 2008 & $10,27,35,40$ \\
\hline 68 & Terpides sooretamae Boldrini \& Salles, 2009 & $04-07,09,10,19,20,26,27,33$ \\
\hline 69 & Thraulodes itatiajanus Traver \& Edmunds, 1967 & $02,14,15,36$ \\
\hline 70 & Thraulodes sp. 1 & 42 \\
\hline 71 & Traverella insolita* Nascimento \& Salles, 2013 & $10,19,26,27$ \\
\hline 72 & Caenis fittkaui Malzacher, 1986 & $08,09,29,35,36,47,48$ \\
\hline 73 & Lachlania sp. 1 & 21 \\
\hline 74 & Lachlania sp. 2 & 16 \\
\hline 75 & Oligoneuria amandae* Salles, Soares, Massariol \& Faria, 2013 & $27 \mathrm{~F}$ \\
\hline
\end{tabular}

Received 31 March 2014; accepted 22 October 2014

Associate Editor: Gustavo Graciolli

Revista Brasileira de Entomologia 58(4): 356-370, December 2014 